\title{
Congenital Hyperinsulinism: Diagnosis and Treatment Update
}

\author{
Hüseyin Demirbilek ${ }^{1}$, Khalid Hussain ${ }^{2}$ \\ ${ }^{1}$ Hacettepe University Faculty of Medicine, Department of Paediatric Endocrinology, Ankara, Turkey \\ ${ }^{2}$ Sidra Medical and Research Center, Clinic of Paediatric Medicine, Doha, Qatar
}

\begin{abstract}
Pancreatic $\beta$-cells are finely tuned to secrete insulin so that plasma glucose levels are maintained within a narrow physiological range (3.5-5.5 mmol/L). Hyperinsulinaemic hypoglycaemia $(\mathrm{HH})$ is the inappropriate secretion of insulin in the presence of low plasma glucose levels and leads to severe and persistent hypoglycaemia in neonates and children. Mutations in 12 different key genes (ABCC8, KCNJ11, GLUD1, GCK, HADH, SLC16A1, UCP2, HNF4A, HNF1A, HK1, PGM1 and PMM2) that are involved in the regulation of insulin secretion from pancreatic $\beta$-cells have been described to be responsible for the underlying molecular mechanisms leading to congenital HH. In $\mathrm{HH}$ due to the inhibitory effect of insulin on lipolysis and ketogenesis there is suppressed ketone body formation in the presence of hypoglycaemia thus leading to increased risk of hypoglycaemic brain injury. Therefore, a prompt diagnosis and immediate management of $\mathrm{HH}$ is essential to avoid hypoglycaemic brain injury and long-term neurological complications in children. Advances in molecular genetics, imaging techniques ( ${ }^{18} \mathrm{~F}$-DOPA positron emission tomography/computed tomography scanning), medical therapy and surgical advances (laparoscopic and open pancreatectomy) have changed the management and improved the outcome of patients with HH. This review article provides an overview to the background, clinical presentation, diagnosis, molecular genetics and therapy in children with different forms of $\mathrm{HH}$.
\end{abstract}

Keywords: Hyperinsulinaemic hypoglycaemia, congenital hyperinsulinaemia, children, diffuse congenital hyperinsulinism, focal congenital hyperinsulinism, sirolimus

\section{Introduction}

Hyperinsulinaemic hypoglycaemia $(\mathrm{HH})$, refers to a clinically, genetically and morphologically heterogeneous group of disorders associated with dysregulated insulin secretion. It is the most common cause of persistent hypoketotic hypoglycaemia in neonates and infants and is associated with a significant risk of permanent brain damage. Therefore, it is essential to make a prompt diagnosis and institute immediate management to prevent complications such as epilepsy, cerebral palsy and neurodevelopemental deficits (1).

The metabolic action of insulin on glucose and fuel metabolism increases the risk of neurological injury. Insulin decreases blood glucose level by increasing its peripheral consumption, stimulates glycogen synthesis and inhibits glycogenolysis and gluconeogenesis. On the other hand, insulin has an anabolic effect on fat tissues. It stimulates lipogenesis, inhibits free fatty acid release, and their beta-oxidation and thus inhibits ketone body formation. This accounts for the hypoketotic state, decreasing the availability of alternative fuels for cerebral metabolism (2). As the brain of neonates and infants has a higher rate of glucose comsumption compared to adult subjects, it is more vulnerable to hypoglycaemic brain injury. HH typically presents in the newborn period with severe hypoglycaemia but can also present in infancy, childhood and even as late as adulthood with variable severity and etiology $(3,4)$.

$\mathrm{HH}$ can be transient due to certain risk factors, such as birth asphyxia, intra-uterine growth retardation, maternal diabetes mellitus (5), or associated with various overgrowth syndromes like Beckwith-Wiedemann syndrome or metabolic conditions such as congenital disorders of glycosylation (6). Genetic forms of $\mathrm{HH}$ congenital hyperinsulinism (CHI) are due to mutation in the genes involved in the regulation of insulin secretion. $\mathrm{HH}$ typically presents with fasting hypoglycemia but can present with postprandial hypoglycaemia or in some 
cases hypoglycaemia can be provoked by protein/leucine loading or even exercise. Patients with HH can vary in their presentation from having no symptoms to having severe, medically unresponsive disease which might require a near total pancreatectomy (7).

Histologically, $\mathrm{CHI}$ is classified into three subgroups: diffuse, focal and atypical forms $(8,9)$. Diffuse disease affects all the islets in the pancreas, whereas in focal disease the abnormality is confined to a small region of the pancreas. Atypical histological forms of $\mathrm{CHI}$ have recently been described (10). Although all the histological subtypes are clinically and biochemically indistinguishable, their differentiation at the histological level is important from the point of the view of management. Recent advances in imaging techniques using ${ }^{18} \mathrm{~F}$-fluoro-L-dihydroxyphenylalanine $\left({ }^{18} \mathrm{~F}\right.$-DOPA) positron emission tomography/computed tomography (PET/CT) have fundamentally changed management strategies, particularly in patients with focal $\mathrm{CHI}(11,12)$.

Mutations in key genes which are involved in the regulation of insulin secretion from pancreatic $\beta$-cells underlie the molecular basis of $\mathrm{CHI}$. Until recently mutations in only 12 different genes (ABCC8, KCNJ11, GLUD1, GCK, HADH, SLC16A1, HNF4A, HNF1A, HK1, PGM1 and PMM2) that lead to dysregulated secretion of insulin had been described $(6,13,14,15,16,17,18)$. More recently there have been single case reports of potentially novel genetic mechanisms of $\mathrm{HH}$ associated with other syndromic features $(19,20)$. In the vast majority of patients who are diazoxide responsive, the genetic basis of $\mathrm{HH}$ is still not known. This review aims to give an overview of the biochemical and molecular basis of $\mathrm{CHI}$ with a focus on describing the latest advances in the diagnosis and treatment of this complex condition.

\section{Physiological Mechanisms Regulating Insulin Secretion from Pancreatic $\beta$-cells in Congenital Hyperinsulinism}

During the intrauterine period the fetus receives glucose across the placenta via facilitated diffusion. After birth, in term healthy newborns with no risk factors for hypoglycemia, plasma glucose levels tend to shows a sharp decline during the first 24-48 hours, but will then normalize to values around 3.5-5.5 mmol/L. This maintenance of a normal plasma glucose concentration requires an adequate supply of exogenous glucose, endogenous fat, glycogen and potential gluconeogenic substrates (e.g. amino acids, glycerol and lactate). In addition, a functional endocrine system that integrates and modulates substrate mobilization, interconversion and utilization is important, as are the key enzymes involved in glycogen synthesis/glycogenolysis, glycolysis, gluconeogenesis, lipolysis and ketogenesis.

The pancreatic $\beta$-cells possesses a signal transduction system, whereby fuel metabolism is intricately linked to regulated insulin secretion (21). Glucose is the most important fuel involved in this so called stimulus-response coupling mechanism. This stimulus response-coupling event is controlled by adenosine triphosphate (ATP)-sensitive potassium channels $\left(\mathrm{K}_{\text {ATP }}\right)$ located in the pancreatic $\beta$-cells membrane (22). Glucose enters the $\beta$-cells through facilitative glucose transporters, particularly glucose transporter 2 (GLUT 2) and is converted to glucose-6-phosphate by the enzyme glucokinase (GCK) (23). GLUT 2 has high affinity for glucose which allows glucose transport in proportion to the plasma glucose concentration (24).

Glycolysis generates high energy molecules such as ATP and this leads to an increase in the ratio of ATP/adenosine diphosphate (ADP) resulting in the closure of the ATP- $\mathrm{K}_{\text {ATP. }}$ The inwardly rectifying potassium (Kir6.2) subunit of the $\mathrm{K}_{\text {ATP }}$ channels are responsible for trafficking of intracellular and extracellular ion exchange, thus maintaining a steady state membrane potential. The closure of the $\mathrm{K}_{\text {ATP }}$ channels results in depolarization of pancreatic $\beta$-cells membranes and activation of intramembraneous voltage-gated calcium channels. Calcium enters into $\beta$-cells through these voltagegated calcium channels and an increase in intracellular calcium triggers secretory granule exocytosis and insulin release (Figure 1).

GCK plays a critical role in acting as a gluco-sensor, providing a link between the extracellular plasma glucose concentration and the metabolism of glucose in $\beta$-cells (25). When the plasma glucose concentration is increased, the activity of GCK is also increased, hence increasing insulin secretion from the $\beta$-cells (Figure 1). Conversely, as the plasma glucose concentration decreases, insulin secretion decreases and serum insulin becomes undetectable when the plasma glucose level is below $3 \mathrm{mmol} / \mathrm{L}(26,27)$.

\section{Clinical Presentation and Biochemical Diagnosis of Hyperinsulinaemic Hypoglycaemia}

Patients with $\mathrm{HH}$ can present with a wide range of symptoms ranging from non-specific adrenergic symptoms (poor feeding, hunger, palpitations, sweating) to life-threatening, neuroglycopenic symptoms (seizures, unconsciousness, lethargy, coma and even death) arising from an inadequate supply of glucose to the brain, resulting in impairment of brain function.

$\mathrm{HH}$ most commonly presents during the neonatal period, but can also present during infancy, childhood and even adulthood $(4,28)$. The clinical presentation of hypoglycaemia is most severe in the newborn and may be quite subtle in infancy and the childhood period. Therefore the diagnosis might be missed until later in life $(29,30,31)$. There can 


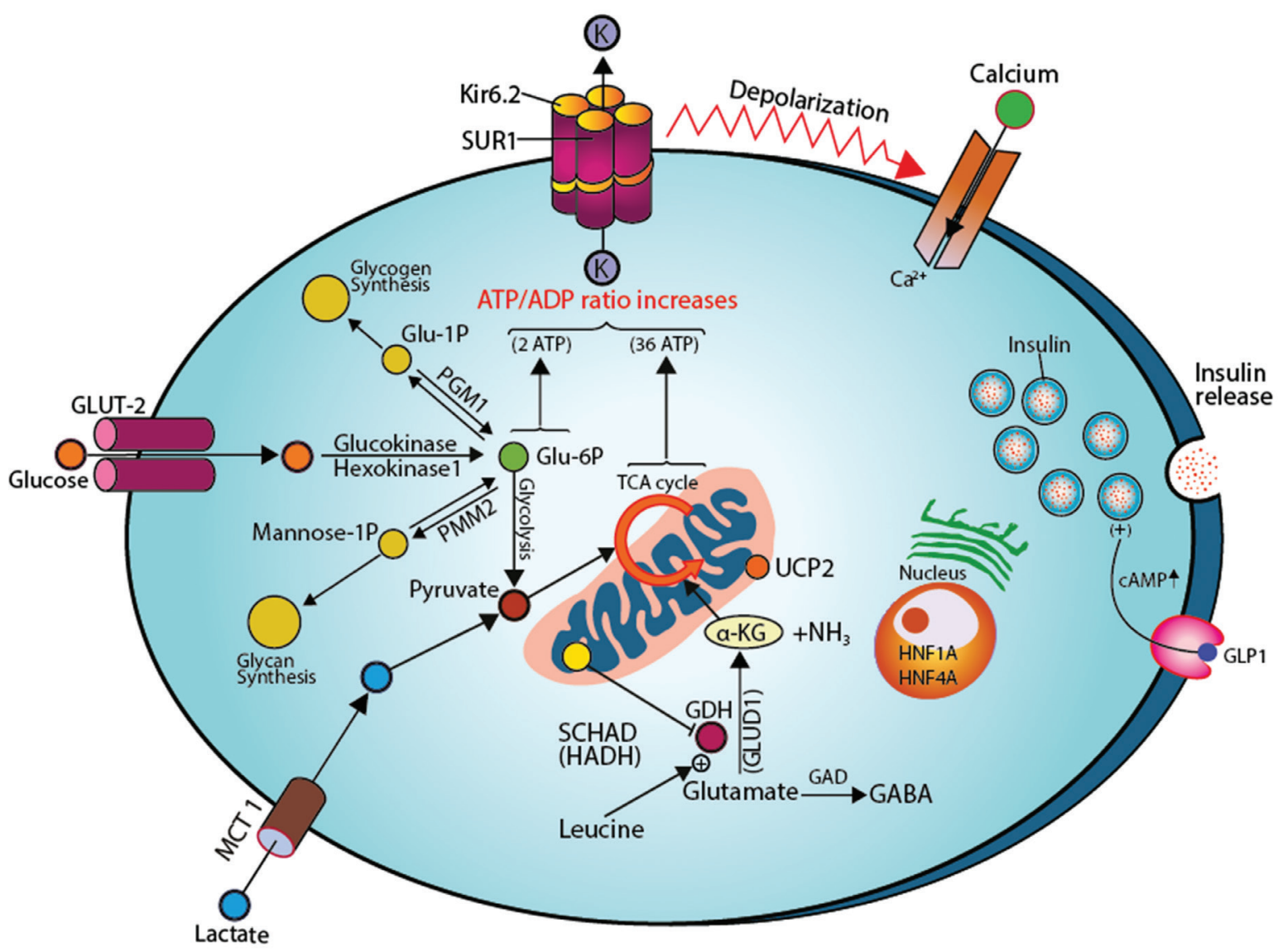

Figure 1. Regulation of insulin release from pancreatic $\beta$-cell and sites of gene mutations involved in the genetics etiology of hyperinsulinaemic hypoglycaemia

SUR1: sulphonlyurea receptor 1, Kir6.2: inwardly rectifying potassium channel 6.2, K: potassium, MCT1: monocarboxylate transporter 1, Glu: glucose, P: phosphorus; PGM1: phosphoglucomutase 1, PMM2: phosphomannose-mutase 2, UCP2: mitochondrial uncoupling protein 2, $\mathrm{NH}_{3}$ : ammonia, GDH: glutamate dehydrogenase, GLUD1: glutamate dehydrogenase 1 gene, SCHAD: short-chain L-3-hydroxyacyl-CoA dehydrogenase, HADH: hydroxy-acyl-CoA dehydrogenase, HNF1A and 4A: hepatocyte nuclear factor 1A and 4A, $\mathrm{Ca}^{+2}$ : calcium; GAD: glutamate decarboxylase enzyme, GABA: $\gamma$-aminobutyric acid, GLP1: glucagon like peptide 1, cAMP: cyclic adenosine monophosphate (amplifier for the exocytosis of insulin secreting granule)

be marked phenotypical variability even within the same family.

Newborns with HH may be macrosomic due to intrauterine hyperinsulinaemia. However, the absence of macrosomia does not exclude $\mathrm{HH}$. Hypertrophic cardiomyopathy and hepatomegaly (increased storage of glucose as glycogen) are observed in some patients with HH. The mechanism of cardiomyopathy and hepatomegaly in these patients is unclear but might be related to the effect of foetal hyperinsulinaemia (1).

Early diagnosis of $\mathrm{HH}$ is fundamentally important in preventing hypoglycaemic brain injury. Hence, clinicians should always be aware of recognising $\mathrm{HH}$ and managing these patients. In any patient with recurrent or persistent hypoglycaemia, $\mathrm{HH}$ should be suspected and critical samples at the time of hypoglycaemic episodes should be collected. An intravenous glucose infusion rate requirement of $>8 \mathrm{mg} / \mathrm{kg} / \mathrm{min}$ (normally is $4-6 \mathrm{mg} / \mathrm{kg} / \mathrm{min}$ ) is virtually diagnostic of $\mathrm{HH}$ (1). In milder forms of $\mathrm{HH}$, it will be important to establish the duration of fasting and whether the hypoglycaemia is precipitated by meals (protein sensitivity) or by exercise.

Biochemically in $\mathrm{HH}$, there is an inappropriate concentration of serum insulin/c-peptide for the level of plasma glucose (spontaneous or provoked). Low or undetectable serum insulin levels during hypoglycaemia do not exclude the diagnosis of HH $(29,30)$. In some cases serum C-peptide levels $(\geq 0.5 \mathrm{ng} / \mathrm{mL})$ and IGFBP-1 $(\leq 110 \mathrm{ng} / \mathrm{mL})$ may help confirm the diagnosis of $\mathrm{HH}$ with specificities of $100 \%$ and $96.6 \%$, respectively (29). The metabolic effect of inappropriate insulin secretion is reflected by inappropriately low levels of serum ketone bodies and fatty acids during hypoglycaemic episodes. There is no correlation between measured serum insulin concentration and the severity of the hypoglycaemia 
(31). In some difficult cases, the diagnosis of $\mathrm{HH}$ should not be based on an isolated serum insulin/c-peptide concentration but on the clinical presentation and the biochemical profiles of insulin action (low $\beta$-hydroxybutyrate and fatty acid concentrations). The diagnostic criteria for $\mathrm{HH}$ are summarized in Table $1(29,32,33)$.

In some instances certain biochemical and clinical features may help in the diagnosis of specific forms of CHI. An elevated serum ammonia concentration in a patient with $\mathrm{HH}$ is suggestive of the hyperinsulinism and hyperammonaemia (HI/HA) syndrome (34). Raised plasma hydroxybutyrylcarnitine and urinary 3-hydroxyglutarate are diagnostic of a rare type of congenital $\mathrm{HH}$ [hydroxyacylCoenzyme A dehydrogenase (HADH) deficiency] (35).

Some types of $\mathrm{HH}$ are elicited only after provocation testing. For example in patients who have the HI/HA syndrome and $H A D H$, protein/leucine loading precipitates hypoglycaemia (36). Patients with exercise-induced $\mathrm{HH}$ will require a formal exercise test and or a pyruvate load to demonstrate post-exercise induced $\mathrm{HH}(37,38)$. In some patients, a positive glycaemic response (rise in the plasma glucose concentration of $>1.5 \mathrm{mmol} / \mathrm{L}$ from baseline) following an intramuscular/intravenous injection of glucagon at the time of hypoglycaemia provides supportive evidence (39). A glycaemic response to a subcutaneous dose of octreotide may also aid diagnosis, along with decreased serum levels of insulin growth factor binding protein-1 (IGFBP-1) as insulin suppresses the transcription of the IGFBP-1 gene (40).

\section{Transient Forms of Hyperinsulinaemic Hypoglycaemia}

There is no precise definition of transient $\mathrm{HH}$, but if the hypoglycaemia resolves spontaneously within a few days (or up to a week) then it might be considered to be transient. Transient HH typically develops in newborns with certain risk factors [such as maternal diabetes mellitus, the use of intravenous dextrose given during labour, intrauterine growth restriction (IUGR), and perinatal asphyxia (Table 1)]. Some newborns with IUGR and asphyxia have a severe and protracted form of $\mathrm{HH}$ which requires treatment with diazoxide (41). The underlying molecular mechanisms in transient cases are not known, but some cases are due to mutations in HNF4A and HNF1A (33). In addition, transient $\mathrm{HH}$ has been described in some newborns with no underlying risk factors (42).

\section{Genetic Forms of Hyperinsulinaemic Hypoglycaemia}

The genetic basis of $\mathrm{CHI}$ involves defects in genes that encode key proteins involved in the regulation of insulin release from the pancreatic $\beta$-cell. These defects lead to disturbances in glucose-stimulated insulin secretion and inappropriate release of insulin from pancreatic $\beta$-cells. Currently, mutations in 12 genes have been reported to cause $\mathrm{CHI}$ and more recently there have been isolated case reports of potential novel genetic mechanisms in patients with $\mathrm{CHI}$ and other syndromic features. The underlying molecular mechanisms that causes $\mathrm{CHI}$ in the vast majority of patients who are diazoxide responsive are still unknown. Table 2 lists the transient and persistent causes of $\mathrm{HH}$.

\section{Table 1. Diagnostic criteria for hyperinsulinaemic hypoglycaemia}

Cardinal diagnostic criteria

Clinical evidence of insulin effects

Supportive evidence (when diagnosis is in doubt or difficult)
Low plasma glucose $<3 \mathrm{mmol} / \mathrm{L}$ with;

Detectable serum insulin

Detectable C-peptide (superior to insulin, as is more stable in blood)

Suppressed/low $\beta$ - hydroxybutyrate and acetoacetate

Suppressed/low serum free fatty acid

Increased requirement of glucose infusion rate ( $>8 \mathrm{mg} / \mathrm{kg} / \mathrm{min}$ )

Positive glycaemic ( $>1.5 \mathrm{mmol} / \mathrm{L}$ ) response to intramuscular/intravenous glucagon

Positive glycaemic response to a subcutaneous/intravenous dose of octreotide

Low serum levels of IGFBP-1 (insulin negatively regulates the expression of IGFBP-1)

Suppressed branch chain (leucine, isoleucine and valine) amino acids

Provocation tests (leucine loading or exercise testing) may be needed in some patients

Normal lactic acid

Normal plasma hydroxybutyrylcarnitine*

Normal ammonia**

Appropriate counterregulatory hormone response***

- Cortisol > $20 \mathrm{mcg} / \mathrm{dL}(500 \mathrm{nmol} / \mathrm{L})$

- Growth hormone $>7 \mathrm{ng} / \mathrm{mL}$

*Elevated in hyperinsulinaemic hypoglycaemia due to hydroxyacyl-CoA dehydrogenase gene mutation, * Elevated in hyperinsulinism-hyperammonemia (HI-HA) syndrome due to glutamate dehydrogenase 1 gene mutation, ${ }^{* * *}$ Counterregulatory hormone response may be blunted in spontaneous, particularly recurring hypoglycaemia, IGFBP-1: insulin-like growth factor binding protein-1 


\section{Genetics of Hyperinsulinaemic Hypoglycaemia}

\section{a) Pancreatic $\beta$-cell KATP Channel Defects}

$\mathrm{K}_{\text {ATP }}$ channels are located in the $\beta$-cell membrane and transduce the metabolic signals generated by glucose metabolism to regulate insulin secretion (33). The $K_{\text {ATP }}$ channel complex is composed of four outer, sulphonlyurea receptor 1 (SUR1) subunits that are encoded by the ATP Binding Cassette Subfamily C Member 8 (ABCC8) gene and the four inner, pore-making, Kir6.2 channel proteins, encoded by the Potassium Voltage-Gated Channel Subfamily J Member 11 (KCNJ11). Both these genes are located on chrosome 11 15.1. The SUR1 component regulates the activity of the Kir6.2 proteins and functions as the binding site for the $K_{\text {ATP }}$ channel opener (diazoxide) and sulphonylureas $(43,44)$. The inner Kir6.2 protein forms a pore allowing potassium influx across the $\beta$-cell membrane. A change in the ratio of ATP to ADP causes closure of the $K_{\text {ATP }}$ channel and triggers depolarisation of the cell membrane, activating the voltagegated calcium channels (45). This in turn causes insulin release through exocytosis $(46,47,48)$.

Mutations in the genes encoding $\mathrm{K}_{\text {ATP }}$ channel proteins are the most common cause of severe CHI $(49,50)$. Recessive inactivating (or loss-of-function) $\mathrm{K}_{\text {ATP }}$ channel gene mutations predominantly cause medically unresponsive diffuse $\mathrm{CHI}(4,6,51,52)$. These mutations can either inhibit the trafficking of channel proteins (SUR1) to the plasma membrane or channel activity (33). Autosomal dominantly inherited mutations usually cause milder forms of $\mathrm{CHI}$ $(53,54)$. Recently a novel phenomenon, describing the combination of heterozygous mutations in the $A B C C 8$ and KCNJ11 genes has been described (55).

\section{b) Glutamate Dehydrogenase (GDH) and Hyperinsulinaemia- hyperammonaemia Syndrome (HI/HA)}

The glutamate dehydrogenase 1 (GLUD1) gene encodes for the mitochondrial matrix enzyme, $\mathrm{GDH}$ which catalyzes the oxidative deamination of glutamate to $\alpha$-ketoglutarate and ammonia (56). GDH is allosterically activated by the amino acid leucine and inhibited by guanosine-5'-triphosphate (GTP) (57). GLUD1 mutations decrease the sensitivity of the allosteric inhibitor, GTP, thereby resulting in a gain-offunction of the GDH enzyme. Dominantly inherited GLUD1 mutations are associated with fasting and leucine (protein) induced postprandial $\mathrm{HH}$, with elevated plasma ammonia (also known as HI/HA syndrome) concentration. Interestingly in a mutant GDH mouse model carrying the $H 454 Y$ mutation, in addition to the loss of GTP inhibition on GDH activity, there was also inhibition of glucagon secretion (58). This inhibition of glucagon secretion may also contribute to the development symptomatic hypoglycemia in these patients (58).
GLUD1 mutations are the second most common cause of CHI. Studies to date have identified mutations in exons 6 , 7, 11 and 12 and 13 (34,59). Although GLUD1 activating mutations are mostly de novo, autosomal dominant forms have also been reported $(59,60)$. HI/HA syndrome patients are diazoxide responsive and in some cases dietary protein restriction might be necessary. Patients with GLUD1 mutations have been reported to develop epileptic seizures regardless of the severity and frequency of hypoglycaemic episodes. Urinary $\alpha$-ketoglutarate is elevated in patients with HI/HA syndrome (61).

\section{c) Mutations in Mitochondrial L-3-Hydroxyacyl-CoA Dehydrogenase (HADH) and CHI}

HADH or short chain L-3-Hydroxyacyl-CoA dehydrogenase is another mitochondrial enzyme that is involved in the penultimate step of $\beta$-oxidation of fatty acids. This gene is most abundantly expressed in pacreatic islet cells, while also present in other extrapancreatic tissues such as the liver, kidneys, muscle and heart (62). The HADH gene has 8 exonic regions and autosomal recessive loss-of-function mutations impair the enzymatic inhibitory effect of $\mathrm{HADH}$ on GDH $(63,64,65)$. This in turn causes a rise in incracellular ATP and inappropriate -leucine sensitive- HH. These observations suggest that GDH plays a pivotal role in fatty acid and amino acid metabolism to control insulin secretion (33). The serum ammonia level is normal in these patients. $H A D H$ gene mutations can lead either to severe neonatal $\mathrm{HH}$ or to mild, late (even adult) onset, protein-induced $\mathrm{HH}$ $(66,67)$. Mutations of $H A D H$ gene have been reported as one of the most common cause of diazoxide responsive $\mathrm{CHI}$ in consanguineous pedigrees. Therefore, $H A D H$ sequence analysis is recommended for all patients with diazoxideresponsive $\mathrm{HH}$ when recessive inheritance is suspected (68). Patient with $H A D H$ mutations may have elevated plasma concentrations of 3-hydroxy-butyryl-carnitine and urinary 3-hydroxy-glutaric acid $(35,65)$.

\section{d) Activating Mutations in GCK and CHI}

GCK catalyses glucose to glucose-6-phosphate conversion as substrate for the glycolytic pathway leading to ATP generation and glucose-dependent insulin release. GCK has high affinity for glucose, serving as a glucose-sensor in pancreatic $\beta$-cells. The GCK gene has 12 exons and encodes the enzyme, GCK. GCK can be found in the pancreatic $\beta$-cells, liver and brain (69). Dominant activating mutations in GCK cause alteration in both protein structure and function. The affinity of mutated GCK enzyme for glucose increases, thereby the threshold for glucose-stimulated insulin release is decreased $(70,71)$. Patients with GCK mutations can have a wide range of clinical presentations. These vary from 


\section{Table 2. Transient and permanent causes of hyperinsulinaemic hypoglycaemia}

\section{Transient causes of $\mathrm{HH}$}

Maternal diabetes mellitus (gestational and insulin-dependent)

Intrauterine growth restriction

Perinatal asphyxia

Rhesus isoimmunisation

HNF4A, HNF1A mutations

\section{Genetic causes of $\mathrm{HH}$}

Mutations in the genes encoding $\mathrm{K}_{\text {ATP }}$ channel proteins SUR1 and Kir6.2

ABCC8

KCNJ11

Mutation in the genes involved in the regulation of insulin secretion

GLUD1

$H A D H$

GCK

SLC16A1

HNF1A

HNF4A

Recently described gene mutations

UCP2

HK1

PGM1

PMM2

FOXA2 (single case report)

CACNA1D (single case report)

\section{Metabolic causes of $\mathrm{HH}$}

Congenital disorders of glycosylation (CGD type $1 \mathrm{a}, 1 \mathrm{~b}$ and $1 \mathrm{~d}$ )

Tyrosinaemia type 1

\section{Other syndromes associated with $\mathrm{HH}$}

Beckwith-Wiedemann syndrome

Kabuki's syndrome

Trisomy 13

Central hypoventilation syndrome

Leprechaunism (insulin resistance syndrome)

Mosaic Turner syndrome

Sotos syndrome

Usher syndrome

Timothy syndrome

Costello syndrome

\section{Miscellaneous causes of $\mathrm{HH}$}

Postprandial $\mathrm{HH}$

Insulin gene receptor mutation

Dumping syndrome

Noninsulinoma pancreatogenous hypoglycaemia syndrome (adults)

Insulin autoimmune syndrome (mostly adults)

Bariatric surgery (adults)

Insulinoma

Non-islet cell tumour hypoglycaemia (adults)

Factitious hypoglycaemia

Drug-induced

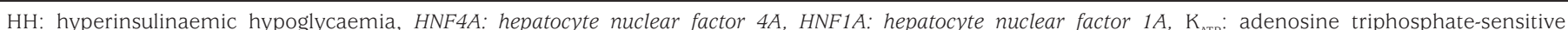

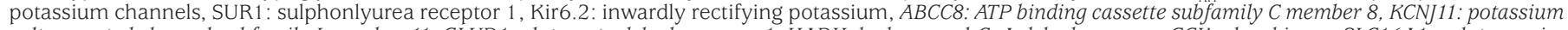

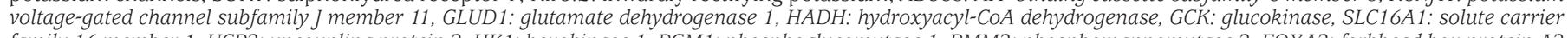

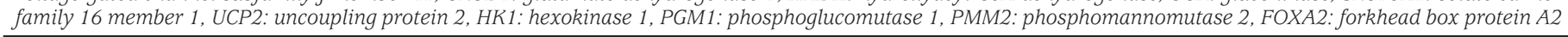


severe, neonatal-onset $\mathrm{HH}$ which is medically unresponsive and requiring surgery to mild, adult-onset $\mathrm{HH}$ which may be asymptomatic $(3,72,73,74,75)$.

\section{e) Mutations in Solute Carrier Family 16 Member 1 (SLC16A1) and Exercise-induced $\mathrm{CHI}$}

Monocarboxylate transporter 1 (MCT1) protein, encoded by the SLC16A1 gene, is involved in the transport of pyruvate and lactate across the $\beta$-cell membrane. These monocarboxylates (pyruvate and lactate) serve as substrates for the Krebs cycle. Under physiological conditions the SLC16A1 gene is silenced in pancreatic $\beta$-cells suggesting that both pyruvate and lactate are prevented from stimulating insulin secretion (33). Dominant gain-of-function mutations in the promotor region of SLC16A1 cause increased expression of MCT1 in $\beta$-cells. This in turn leads to glycolysis-generated pyruvate to continually enter the Kreb's cycle and stimulate insulin secretion in states of low plasma glucose during anaerobic exercise, and in particular strenuous exercise (76). A pyruvate load or excercise test may precipitate HH and may be used for diagnostic purposes (38). These patients are often diazoxide responsive and avoiding strenuous exercise is advised (37).

\section{f) Hepatocyte Nuclear Factor (HNF) 1A\&4A (HNF1A\&4A) and CHI}

The HNFs, HNF $1-\alpha$ and HNF4- $\alpha$, are transcription factors for nuclear hormone receptors expressed in pancreatic $\beta$-cells and regulate glucose-dependent insulin secretion $(77,78)$. The hepatocyte nuclear factors $1 \mathrm{~A}$ and $4 \mathrm{~A}$ genes (HNF1A/HNF4A) encode for the HNF1- $\alpha$ and HNF4- $\alpha$ proteins, respectively. Heterozygous loss-of-function mutations in HNF4A and HNF1A lead to $\mathrm{HH}$ in the newborn period and maturity onset-diabetes (type 1 and 3) later in life $(79,80,81,82)$. CHI due to mutations in both HNF1A and HNF4A are characterized by macrosomic birth and mild transient to severe diazoxide-responsive $\mathrm{HH}$ $(6,13,52,79,83,84,85)$. CHI due to HNF4A gene has been reported with increased levels of glycogen in erythrocytes, elevated liver transaminases and increased echogenicity on liver ultrasonography, suggesting a glycogenosislike phenotype $(86,87)$. In some patients with diazoxide responsive $\mathrm{HH}$, mutations in $H N F 1 A$ and $H N F 4 A$ may be common $(85,88)$.

\section{g) Mutations in the Mitochondrial Uncoupling Protein 2 (UCP2) and $\mathrm{CHI}$}

$U C P 2$, an inner mitochondrial carrier protein which encoded by the UCP 2 gene, is widely expressed in tissues, including pancreatic islets $(89,90)$. UCP2 mediates proton leak across the inner mitochondrial membrane, thereby inhibiting ATP generation through mitochondrial oxidative metabolism and negatively regulates glucose mediated insulin secretion
$(90,91)$. Inactivating heterozygous mutations of the UCP2 gene would therefore, enhance glucose oxidation and increase intracellular ATP synthesis leading to HH $(90,92)$. $\mathrm{CHI}$ due to UCP2 mutations can present with a clinical phenotype ranging from transient $\mathrm{HH}$ to prolonged $\mathrm{HH}$ $(28,90,93)$. In one study UCP2 variants were found in $2.4 \%$ from a cohort of 211 diazoxide responsive patients (28). However, in a more recent study, no protein truncated variants were detected in the UCP2 gene among 206 diazoxide responsive patients (94). The only variant detected was considered to be a common polymorphism. This suggests, therefore, that the role UCP2 in CHI needs further investigation.

\section{h) Somatic overexpression of Hexokinase 1 (HK1) and CHI}

HK1 is located on chromosome 10 and encodes the enzyme; HK1. Hexokinases are a group of enzymes that catalyse the first step of glucose metabolism, of which HK1 is the predominant enzyme. It catalyses the phosphorylation of glucose to produce glucose-6-phosphate as substrate for glycolysis. Normally, HK1 expression is silenced in the pancreatic $\beta$-cells. Recently however, a report identified a dominant gain-of-function mutation in the $H K 1$ gene in a family with "idiopathic hypoglycaemia of infancy" (17). Further evidence for the role of overexpression of HK1 has been reported in an in vitro study evaluating pancreatic specimens of five $\mathrm{CHI}$ cases which showed inappropriate expression of "HK1" in a subset of pancreatic $\beta$-cells. In these pancreatic specimens the $K_{\text {ATP }}$ channel was functional but there was inappropriate insulin secretion at low plasma glucose levels (1 mmo/L) (95).

\section{i) Phosphoglucomutase 1 (PGM1) Gene Mutations and CHI}

PGM1 catalyses the reversible conversion of glucose-6phosphate to glucose-1-phosphate involved in glycogen metabolism. Recently, a recessive loss-of-function mutation in the PGM1 gene that encodes the enzyme PGM1 has been shown to be associated with hypoglycaemia, similar to glycogenosis (18). Patients with these inactivating mutations have an exaggerated glucose-mediated insulin secretion and therefore present with fasting hyperketotic hypoglycaemia, as well as postprandial $\mathrm{HH}$ (15).

\section{j) Phosphomannomutase 2 (PMM2) Gene Mutations and CHI}

The enzyme PMM2 is involved in glycosylation and the PMM2 gene has recently been reported to cause $\mathrm{HH}$ as well as congenital polycystic kidney disease in 17 children from 11 unrelated families (16). The group reported a promoter mutation (c. $167 \mathrm{G}>\mathrm{T}$ ) in the PMM2 gene in all affected patients. This mutation has been shown to alter insulin secretion from pancreatic $\beta$-cells. 


\section{k) Mutations in CACNA1D and CHI (Single Case Report)}

CACNA1D encodes an L-type voltage-gated calcium channel that plays a pivotal role in the regulation of insulin secretion from pancreatic $\beta$-cells. A patient with a CACNA1D gene mutation has been reported with $\mathrm{HH}$, heart defects and severe hypotonia (20) but the molecular mechanism leading to $\mathrm{HH}$ is still not clear.

\section{I) Mutations in Forkhead Box Protein A2 (FOXA2) and CHI (Single Case Report)}

A case has been reported of a mutation in FOXA2 with hypopituitarism, $\mathrm{HH}$ and endoderm-derived organ abnormalities (19). Again the moleclar basis of the $\mathrm{HH}$ observed in the patient was not elucidated.

\section{Hyperinsulinaemic Hypoglycaemia Management}

The cornerstone of clinical management involves the early diagnosis and starting of appropriate therapy for patients with all forms of HH. The aim is to keep plasma glucose levels above $3.5 \mathrm{mmol} / \mathrm{L}$ given that the brain is deprived of alternative substrates. The treatment options includes medical, surgical or sometimes combination therapies.

\section{Emergency Management}

Parenteral glucose infusion: If the patient is unable to take an oral feed then $2 \mathrm{mls} / \mathrm{kg}$ of $10 \%$ glucose should be administered intravenously as a bolus. In some instances, a repeat bolus may be required, but further repeated boluses should be avoided, as the bolus of glucose is a potent trigger for insulin secretion. Normoglycemia should be achieved by delivering a continuous intravenous glucose infusion starting with 6-8 $\mathrm{mg} / \mathrm{kg} / \mathrm{min}$. Patients with $\mathrm{HH}$ may require $>25 \mathrm{mg} / \mathrm{kg} / \mathrm{min}$ of intravenous glucose infusion to maintain normoglycaemia.

Glucagon administration: Glucagon is a key counterregulatory hormone and is used as a first line therapy for managing $\mathrm{CHI}$ patients, particularly in emergency situations where patients are unable to take oral feed and/or intravenous access is difficult to obtain $(32,96)$. Glucagon, in the shortterm, induces glycogenolysis, gluconeogenesis and lipolysis and causes a rapid increase in plasma glucose within a few minutes after administration. The recommended single dose is $0.5-1 \mathrm{mg}$ via intramuscular or subcutaneous injection. Glucagon, in high doses (over $1 \mathrm{mg}$ ), can cause rebound hypoglycemia due to a paradoxical increase in insulin secretion (97). Long-term non-surgical management of $\mathrm{CHI}$ using continuous subcutaneous glucagon infusion at a rate of $5-10 \mathrm{mcg} / \mathrm{kg} / \mathrm{hour}$ in combination with octreotide have been reported $(98,99)$.

Frequent feeding: Frequent feeding with high calorie carbohydrate feeds may reduce the frequency and severity of hypoglycaemic episodes. However, patients wth $\mathrm{CHI}$, particularly those on diazoxide therapy usually have food aversion. Therefore a percutaneous gastrostomy is sometimes recommended to allow frequent (or continuous) feeding $(100,101)$. Using complex carbohydrate such as uncooked cornstarch may decrease the hypoglycaemic episodes and improve fasting tolerance during a prolonged overnight fast in children over the age of one year.

\section{Long-term Management}

A long-term management plan should be individualized for each patient and aim to normalize plasma glucose levels, provide an age-adjusted fasting tolerance and avoid neurological symptoms associated with hypoglycemia. Pharmacological therapy should be introduced one at a time to gauge the response and carefully monitored for side effects.

Diazoxide: Diazoxide, a $\mathrm{K}_{\text {AтP }}$ channel opener, is invaluable for managing many patients with $\mathrm{CHI}(1,32,96,102)$. Diazoxide is usually effective in all forms of $\mathrm{CHI}$ where the $\mathrm{K}_{\text {ATP }}$ channel function is intact but patients with recessive (and some dominant) $K_{\text {ATP }}$ channel mutations do not respond to diazoxide (1). Diazoxide functions by binding to the SUR1 subunit of $K_{\text {ATP }}$ channel. Thus, it requires a functionally intact $K_{\text {ATP }}$ channel. Diazoxide responsiveness has been the key for molecular genetics analysis, differential diagnosis and management strategies of $\mathrm{CHI}$. In diazoxide unresponsive $\mathrm{CHI}$ cases, urgent genetic analysis for $\mathrm{ABCC}$ / KCNJ11 and ${ }^{18} \mathrm{~F}$-DOPA-PET/CT scan are indicated to identify those patients who could have the focal form of $\mathrm{CHI}$. In a recent study, diazoxide responsive patients with $\mathrm{CHI}$ who carry paternally inherited $A B C C 8$ or KCNJ11 mutations have been reported and thus it was suggested that these patients should also undergo scanning with ${ }^{18} \mathrm{~F}-\mathrm{DOPA}$ PET/CT (103).

The initial dose of diazoxide is $5 \mathrm{mg} / \mathrm{kg} /$ day, in three divided doses which can be increased up to a maximum dose of $15-20 \mathrm{mg} / \mathrm{kg} /$ day (104). The citeria for diazoxide responsiveness include an age adjusted fasting tolerance, able to maintain normoglycaemia and have a normal feeding plan. The most severe side effect that limits and requires treatment withdrawal is fluid retention, cardiac failure and the associated electrolyte imbalance. Diazoxide induced pulmonary hypertension is another life-threatening side effect which requires treatment withdrawal and therefore the FDA has issued a drug safety communication warning $(105,106,107,108)$. In the newborn period a thiazide diuretic (such as chlorothiazide $7-10 \mathrm{mg} / \mathrm{kg} /$ day in two divided doses), is usually administered with diazoxide to prevent fluid retention. Other side effects of diazoxide therapy are described in Table $3(33,102,109)$.

Octreotide: Octreotide, is an eight amino acid, synthetic, long-acting somatostatin analogue that inhibits insulin 
secretion by binding to somatostatin receptors 2 and 5 (SSTR2 and SSTR5) (110). Activation of SSTR5 decreases insulin gene promoter activity, inhibits calcium mobilization and acetylcholine activity (111). Somatostatin also inhibits the $K_{\text {ATP }}$ channel which results in reduced insulin secretion (96). The recommended initial dose of octreotide is $5 \mu \mathrm{g} / \mathrm{kg} /$ day given by subcutaneous injections (or as a continuous infusion) at 6-8h intervals with a maximum dose of 30-35 $\mu g / \mathrm{kg} /$ day. Long-term, continuous, subcutaneous octreotide infusion with an insulin pump has also been reported as a feasible alternative to surgery for patients with monoallelic $\mathrm{K}_{\text {ATP }}$-channel mutations (112). The first response to octreotide administration is usually hyperglycaemia followed by a blunted effect after 48 hours (tachyphylaxis). Thus dose adjustment may be required $(32,113,114)$. Although various side effects have been reported in case reports, in a study evalutaing the long-term safety and efficacy of octreotide in a large series of $\mathrm{CHI}$ patients, it was found to be a safe and effective treatment for diazoxide unresponsive CHI patients $(102,115,116,117,118,119,120,121,122$, 123) (Table 3). The effect of octreotide on linear growth have been found clinically insignificant $(102,117,123)$. In a recent clinical trial, monitoring the serum concentration of octreotide is recommended for dose titration, in order to avoid paradoxically diminished effectiveness and to reduce the side effects, thereby achieving optimal doses for highest efficacy and safety (123).

Long-acting somatostatin analogs: As conventional octreotide therapy requires multidose daily injections, this causes a burden to the patients and family, reduces adherence to the treatment and impacts negatively on quality of life (QoL). Monthly injection of long-acting somatostatin analogs have been described as an effective option in the management of $\mathrm{CHI}$. Long-acting octreotide release (LAR) is formulated with biodegradable microspheres (124). This formulation increases the half-life with the advantage of being administrated every 28 days. Lanreotide is also a synthetic octapeptide and it can be adminstered every 28 days. LAR-octreotide and lanreotide have been used successfully in children with $\mathrm{CHI}$, even in early infancy $(102,125,126,127,128,129,130,131)$. Using LAR once every four weeks increases the treatment adherence and improves QoL (125).

Nifedipine: As the voltage gated calcium channel plays a key role in insulin secretion from the pancreatic $\beta$-cell, nifedipine, an L-type calcium channel blocker, has been used in the treatment of CHI (132). There have been several case reports demonstrating the effectiveness of Nifedipine in CHI patients. $(133,134,135,136,137,138)$. In a recent study exclusively investigating long-term use of nifedipine in eleven $\mathrm{CHI}$ cases with $A B C C 8$ mutations, none of patients showed any improvement in glycemic control and patients continued to have hypoglycemic episodes (139). This suggests that mutations in the $\mathrm{K}_{\mathrm{ATP}}$ channel genes might render the L-type calcium channel ineffective to therapy with nifedipine (139) The recommended dose is $0.25-2.5$ $\mathrm{mg} / \mathrm{kg} /$ day divided into 2-3 doses (96). Hypotension is an uncommon side-effect (96), especially at doses above 0.5 $\mathrm{mg} / \mathrm{kg} / \mathrm{day}$ (134) (Table 3).

\section{New and Potential Future Therapies}

Although our knowledge of the molecular basis of $\mathrm{CHI}$ has advanced, there are still challenges in managing patients who are diazoxide unresponsive. Most patients with diffuse $\mathrm{CHI}$ who are diazoxide unresponsove will typically require a near total pancreatectomy. In some patients, despite this major surgery, hypoglycemia persisted. Thus novel medical treatments are required to try and avoid a near total pancreatectomy which is not always curative.

Sirolimus: Sirolimus, an immunosuppressive agent with an anti-proliferative ability, inhibits the mammalian target of rapamycin (mTOR), a serine/threonine kinase (140). mTOR regulates cellular growth by stimulating protein synthesis and increasing mRNA translation initiation $(141,142)$. The mechanism of action for mTOR inhibitors in $\mathrm{CHI}$ has not been fully elucidated. However, it is reported that there is constitutive activation and overexpression of p-mTOR on the plasmalemmal aspect of the acinar cells and activation on the plasmalemmal aspect of the ductal cells in the diffuse variant of CHI (143). Recently, another mechanism has been proposed; that sirolimus causes depletion of intracellular $\mathrm{Ca}^{2+}$ stores and alters mitochondrial activity, eventually leading to decreased insulin release (140). Upregulation of mTOR leads to increased insulin release from the pancreatic $\beta$-cells (144). Conversely, mTOR inhibition with rapamycin reduces insulin secretion as well as $\beta$-cell growth (145). Sirolimus can also enhance $\beta$-cell apoptosis and insulin resistance by reducing islet mass, insulin content and insulin sensitivity (140). mTOR also inhibits peroxisome proliferators-activated receptor- $\gamma$ activity thereby affecting ketone body synthesis (146).

Sirolimus has been reported to be an effective and safe drug for severe, diazoxide unresponsive, diffuse $\mathrm{CHI}$ with no major side effects (147). Following the first report, significant numbers of cases have been reported $(148,149,150,151,152,153,154)$. As sirolimus has potentially adverse effects (perhaps related to dose) arising from its immunosuppressive effects, measurement of the blood levels is vitally important for reaching an optimal therapeutic level. The most commonly reported adverse effects are stomatitis, increased risk of infection, immunosuppression, 
Table 3. Drugs for medical therapy of hyperinsulinaemic hypoglycaemia

\begin{tabular}{|c|c|c|c|c|}
\hline \multicolumn{2}{|l|}{ Route } & Dose & Mode of action & Side effects \\
\hline \multicolumn{5}{|c|}{ Conventional medicines } \\
\hline \multirow[t]{2}{*}{ Diazoxide } & Oral & $\begin{array}{l}\text { 5-20 mg/kg/day, in } 3 \text { divided } \\
\text { doses }\end{array}$ & $\begin{array}{l}\text { Bind to SUR1 subunit of KATP } \\
\text { channels, opens the channels and } \\
\text { inhibits insulin secretion }\end{array}$ & $\begin{array}{l}\text { Common: Water and salt } \\
\text { retention, hypertrichosis, loss } \\
\text { of appetite }\end{array}$ \\
\hline & & & $\begin{array}{l}\text { Needs an intact } K_{\text {AтP }} \text { channel to } \\
\text { work properly }\end{array}$ & $\begin{array}{l}\text { Rare: Cardiac failure, } \\
\text { pulmonary hypertension, } \\
\text { hyperuricaemia, blood } \\
\text { dyscrasias (bone marrow } \\
\text { suppression, anaemia, } \\
\text { eosinophilia etc.), paradoxical } \\
\text { hypoglycaemia }\end{array}$ \\
\hline Chlorothiazide & Oral & $\begin{array}{l}\text { 7-10 } \mathrm{mg} / \mathrm{kg} / \text { day, in } 2 \text { divided } \\
\text { doses }\end{array}$ & $\begin{array}{l}\text { Prevents fluid retention, synergistic } \\
\text { effects with diazoxide on KATP } \\
\text { channels to inhibit insulin } \\
\text { secretion }\end{array}$ & $\begin{array}{l}\text { Hyponatraemia, } \\
\text { hypokalaemia }\end{array}$ \\
\hline \multirow[t]{2}{*}{ Octreotide } & S.C & $\begin{array}{l}5-35 \mu \mathrm{g} / \mathrm{kg} / \text { day, divided to } \\
\text { 3-4 doses or continuous } \\
\text { subcutaneous infusion }\end{array}$ & $\begin{array}{l}\text { Activation of SSTR2 and SSTR5 } \\
\text { inhibits calcium mobilization and } \\
\text { acetylcholine activity, decreases } \\
\text { insulin gene promoter activity, } \\
\text { reduces insulin biosynthesis and } \\
\text { insulin secretion }\end{array}$ & $\begin{array}{l}\text { Acute: Anorexia, nausea, } \\
\text { abdominal discomfort, } \\
\text { diarrhoea, drug induced } \\
\text { hepatitis, elevated liver } \\
\text { enzymes, long QT syndrome, } \\
\text { tachyphylaxis, necrotizing } \\
\text { enterocolitis }\end{array}$ \\
\hline & & & & $\begin{array}{l}\text { Long-term: Decreases } \\
\text { intestinal motility, bile sludge } \\
\text { and gallstone, suppression of } \\
\text { pituitary hormones (Growth } \\
\text { hormone, TSH) }\end{array}$ \\
\hline \multicolumn{5}{|l|}{$\begin{array}{l}\text { New } \\
\text { medicines }\end{array}$} \\
\hline $\begin{array}{l}\text { Rapamycin } \\
\text { (sirolimus, } \\
\text { everolimus) }\end{array}$ & Oral & $\begin{array}{l}\text { An initial dose of } 1 \mathrm{mg} / \\
\mathrm{m}^{2} \text { per day may require } \\
\text { dose adjustment according } \\
\text { to blood sirolimus } \\
\text { concentration aiming to } \\
\text { keep between } 5-15 \mathrm{ng} / \mathrm{mL}\end{array}$ & $\begin{array}{l}\text { mTOR inhibitor. Inhibit insulin } \\
\text { release and } \beta \text {-cell proliferation } \\
\text { through different mechanisms } \\
\text { which have not been clarified yet }\end{array}$ & $\begin{array}{l}\text { Immune suppression, } \\
\text { mucositis, hyperlipidemia, } \\
\text { elevation of liver enzymes, } \\
\text { thrombocytosis, impaired } \\
\text { immune response to BCG } \\
\text { vaccine }\end{array}$ \\
\hline $\begin{array}{l}\text { Octreotide } \\
\text { LAR/ } \\
\text { Lanreotide }\end{array}$ & deep s.c & $\begin{array}{l}\text { Dose is calculated using } \\
\text { cumulative current multi- } \\
\text { injection dose of octreotide } \\
\text { and given as a single dose } \\
\text { every } 4 \text { weeks or a total } \\
\text { dose of } 15-60 \text { mg/every } 4 \\
\text { weeks }\end{array}$ & $\begin{array}{l}\text { These long acting somatostatin } \\
\text { analogues have similar effects to } \\
\text { daily multidose octreotide }\end{array}$ & $\begin{array}{l}\text { Similar to daily multiple } \\
\text { injection octreotide. However, } \\
\text { long-term follow up is not } \\
\text { known yet }\end{array}$ \\
\hline
\end{tabular}

SUR1: sulphonlyurea receptor $1, \mathrm{~K}_{\text {ATP: }}$ adenosine triphosphate-sensitive potassium channels, S.C: subcutaneous, i.m: intramuscular, i.v: intravenous, SSTR2: somatostatin receptors 2, SSTR5: somatostatin receptors 5, TSH: thyroid-stimulating hormone, BCG: Bacillus Calmette-Guérin, mTOR: mammalian target of rapamycin, LAR: long-acting release 
renal dysfunction, fatigue, pneumonitis and increased serum aminotransferase or lipid levels (155).

In a recent report evaluating the efficacy of sirolimus in 10 patients with diazoxide unresponsive $\mathrm{CHI}$, mTOR inhibition has shown to be effective in only three patients $(30 \%)$ with certain side effects (156). In addition, pancreatic tissue from two patients who did not respond to sirolimus showed no reduction in $\beta$-cell proliferation. Therefore it was claimed that inhibition of mTOR signaling does not down-regulate the $\beta$-cell proliferation in patients with $\mathrm{CHI}$ (156). Thus furthur studies, ideally in the form of clinical trails are required to assess the efficacy of mTOR inhibitors in $\mathrm{CHI}$ patients.

\section{Glucagon-like peptide-1 Receptor Antagonist: Exendin-(9-39)}

GLP-1 is an incretin hormone produced in enteroendocrine L-cells of the intestine in response to ingested nutrients (157). GLP-1 enhances insulin secretion by binding to a guanine nucleotide binding protein-coupled receptor (158), resulting in the activation of adenylate cyclase and generation of cAMP (159). GLP-1 stimulates insulin secretion by both protein kinase A-dependent and -independent mechanisms (160) and also inhibits glucagon secretion, hepatic glucose production, gastric emptying and appetite.

Exendin-(9-39) is a specific GLP-1 receptor antagonist in mice and humans $(161,162)$. In Sur-1 knock-out mice it was shown that Exendin-(9-39) decreases cAMP levels and inhibits insulin secretion thereby raising fasting plasma glucose levels (163). Another study demonstrated that exendin-(9-39) prevents hypoglycemia and maintains normoglycemia during a prolonged fast in individuals with $\mathrm{K}_{\text {ATP }}$ mutations (164). These promising results point to the GLP-1 receptor as a therapeutic target for $K_{\text {ATP }}$ mutations. More recently, in the first population pharmacokinetic

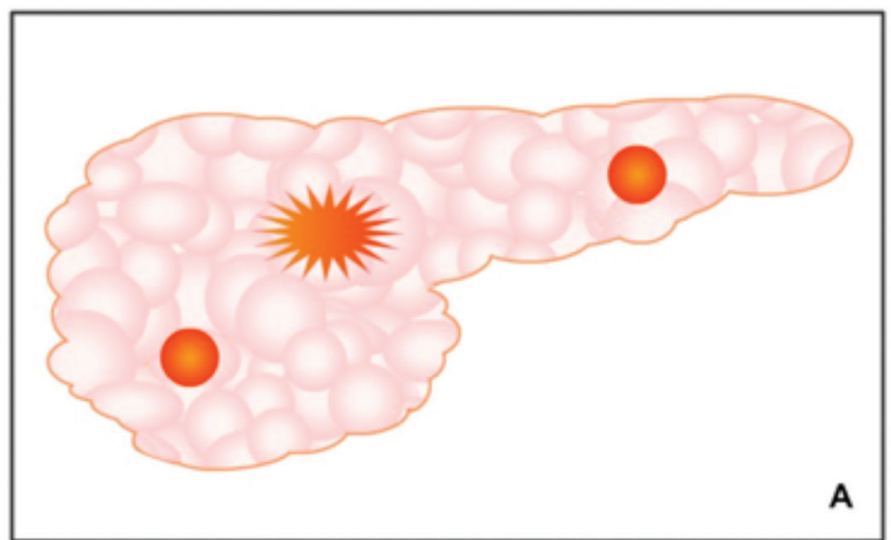

model of exendin-(9-39) in patients with $\mathrm{CHI}$, the maximum recommended starting dose was determined to be $27 \mathrm{mg} /$ $\mathrm{kg} /$ day, intravenously (165). This result informs the optimal dosing regimen for future clinical trials in neonates with $\mathrm{CHI}$.

Ketogenic diet: $\mathrm{CHI}$ typically deprives the brain of both its main and alternative energy sources, being glucose and ketone bodies respectively. During the suckling period, ketone bodies constitute the main energy substrate for the brain. However, in the adult brain glucose is the main energy source (166). An increase in the ketone body concentration increases their oxidation rate in the brain $(167,168)$. Thus, ketogenic diets have been used as an adjunctive therapeutic option in refractory epilepsy and in experimental models of ischemia and excitotoxicity (169). HH induces severe neuroglycopenia and also inhibits gluconeogenesis, glycogenolysis, lipolysis and, eventually, fatty acid oxidation which results in suppressed ketone body synthesis. This makes the brain more vulnerable to the neurological insult of hypoglycaemia. Maiorana et al (170) reported a trial ketogenic diet administered to a child with $\mathrm{CHI}$ due to a spontaneous GCK activating mutation and recurring hypoglycaemic episodes, despite medical therapy. After the first six months, the patient was free of epileptic seizures, with normalization of EEG and showed a marked recovery in psychological development and QoL (170). Although this treatment requires further investigation these initial findings suggest that a ketogenic diet could have a neuroprotective effect in selected cases of $\mathrm{CHI}$.

\section{Histologic Subtypes of Congenital Hyperinsulinaemic Hypoglycaemia}

In terms of histology, there are three forms of CHI; focal, diffuse, and atypical disease (Figure 2). In focal $\mathrm{CHI}$ the

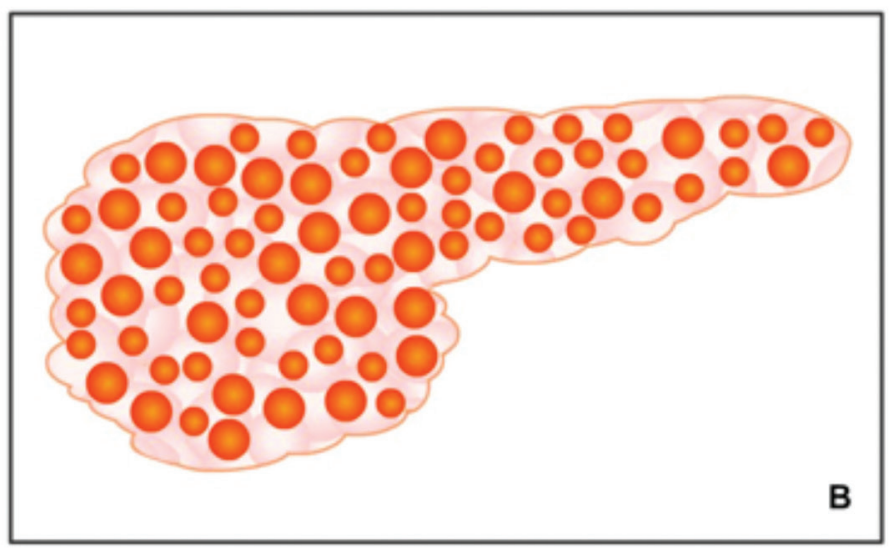

Figure 2. A schematic representation of focal and diffuse congenital hyperinsulinism. In the focal disease (A), the $\beta$-cell hyperplasia is limited to a certain are of the pancreas gland with a superficial or deep localization or invades as a tentacle shape. In the diffuse disease (B) there is a global $\beta$-cell hyperplasia throughout the whole panreas 
abnormal pancreatic $\beta$-cells are localised to a specific region of the pancreas. Focal pancreatic lesions are generally 2-10 $\mathrm{mm}$ in size and appear as small regions of islet adenomatosis (nodular hyperplasia of islet-like cell clusters, including ductuloinsular complexes, Figure 3) (33). Islet cells in the lesion have large cytoplasm with dispersed abnormal nuclei of irregular shape (171).

Focal disease is mostly sporadic and is associated with a paternally inherited $K_{\text {ATP }}$ channel mutations and the loss of maternal heterozygosity for $11 \mathrm{p}$ in the focal area (172). This in turn induces the expression of insulin-like growth factor 2, inhibits the tumor suppressor genes H19 and cyclin-dependent kinase inhibitor $1 \mathrm{C}$ and leads to $\beta$-cell proliferation (173). ${ }^{18} \mathrm{~F}$-DOPA-PET scanning is currently the only diagnostic imaging tool to accurately localize focal lesions (174). Pancreatic islets are able to uptake L-DOPA and convert it to dopamine through DOPA decarboxylase. The uptake of the positron emitting tracer ${ }^{18} \mathrm{~F}$-DOPA-PET is increased in $\beta$-cells with a high rate of insulin synthesis and secretion compared to unaffected areas (Figure 3). The sensitivity for detecting focal lesions varies between 88 and $94 \%$ with an accuracy of $100 \%$ (175). In a recent study ${ }^{18} \mathrm{~F}-\mathrm{DOPA}-\mathrm{PET} / \mathrm{CT}$ was found to be superior in localizing focal lesions compared to imaging with ${ }^{68} \mathrm{Ga}$-DOTANOC PET/ CT (176). Patients with focal CHI are usually unressponsive to medical therapy and require a surgical lesionectomy.

Diffuse disease accounts for about $60 \%$ of all $\mathrm{CHI}$ cases and affects all the $\beta$-cells of the pancreas. Morphology of the islets of Langerhans typically show the presence of $\beta$-cells with abnormally large nuclei (Figure 3) (177). Patients with diffuse $\mathrm{CHI}$ mostly have either a homozygous recessive or a compound heterozygous mutations in $\mathrm{K}_{\text {ATP }}$ channel genes (8). Patients are usually unresponsive to medical therapy and require a near-total pancreatectomy (95-98\% removal).

In some cases pancreatic histology does not fit the typical focal or diffuse appearance and therefore atypical forms of

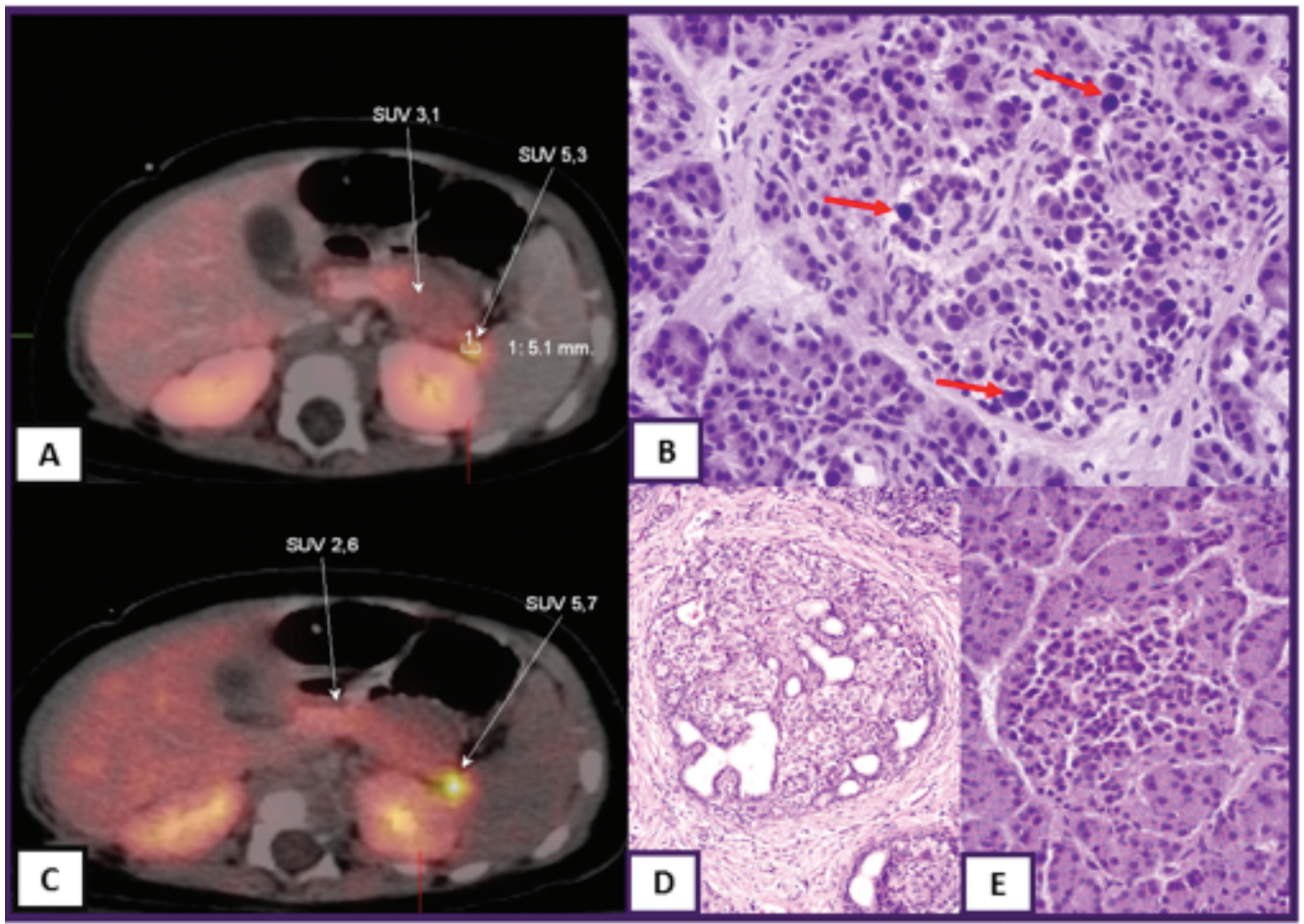

Figure 3. ${ }^{18} \mathrm{~F}$-fluoro-L-dihydroxyphenylalanine $\left({ }^{18} \mathrm{~F}-\mathrm{DOPA}\right)$-positron emission tomography/computed tomography scan images of focal congenital hyperinsulinism (A and C), histological figure of diffuse (B) and focal (D) disease and normal pancreas islet cell (E). Standardized uptake value (SUV) 5.3 and SUV 5.7 indicate focal uptake of ${ }^{18} \mathrm{~F}-\mathrm{DOPA}$, red arrows show large nuclei of $\beta$-cell in diffuse disease 
CHI have been described $(178,179,180)$. In atypical forms some islets show signs of hyperplasia interpersed with histologically normal looking islets. Some patients with $\mathrm{CHI}$ have morphological mosaicism including coexistence of two types of islet; large islets with cytoplasm-rich cells and occasional enlarged nuclei and shrunken islets with cells exhibiting little cytoplasm and small nuclei (173).

\section{Surgical Therapy}

Differentiation of the histological subtypes is essential for successful surgical outcome. Recent advances in the molecular genetics of $\mathrm{CHI}$ and imaging with ${ }^{18} \mathrm{~F}$-DOPA-PET/ CT have changed the management of patients, particularly those with focal disease (177). In diffuse disease there is uptake of ${ }^{18} \mathrm{~F}$-DOPA throughout the pancreas on the PET/ CT scan whereas in focal forms there is limited uptake of ${ }^{18} \mathrm{~F}-\mathrm{DOPA}$ in a localised region of the pancreas. Once this focal lesion is localised on the PET/CT it is possible to surgically remove the lesion and cure the patient of hypoglycemia
(Figure 3) (181,182). Intraoperative frozen sections are important as these can both confirm the histological diagnosis and to determine the margin of resection (183).

Surgery for diffuse and atypical disease: Patients with diffuse and atypical disease usually require extensive surgery (subtotal- or near-total pancreatectomy). This procedure caries a high risk of developing pancreatic exocrine insufficiency and diabetes which requires life-long pancreatic enzyme replacement and insulin therapy $(7,184,185,186,187)$. In near-total pancreatectomy, the tail, body, uncinate process and part of the pancreatic head are resected, leaving a rim of pancreatic tissue surrounding the common bile duct and along the duodenum (7). However, despite extensive resection (95-98\% of pancreatic tissue) some children continue to have HH (185). Diabetes can develop immediately after surgery or later during follow-up (184). Therefore, patients who undergo surgical resection should be monitored for glucose metabolism and diabetes $(184,185,186,187)$.

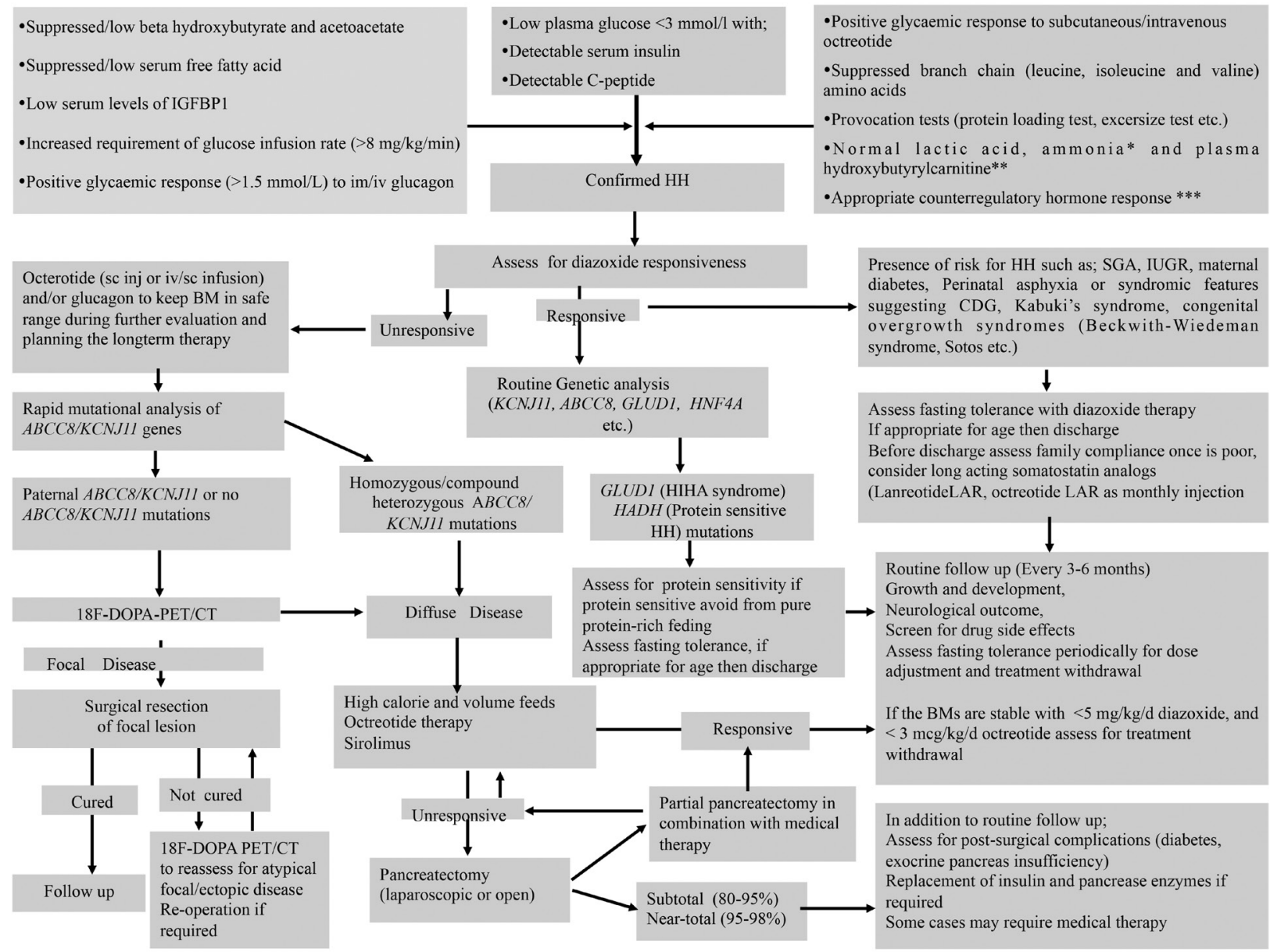

Figure 4. An algorithm for the diagnosis and management of hyperinsulinaemic hypoglycaemia

HH: hyperinsulinaemic hypoglycaemia, IGFBP-1: insulin growth factor binding protein-1, HNF4A: hepatocyte nuclear factor 4A, ABCC8: ATP binding cassette subfamily Cmember 8, KCNJ11:potassium voltage-gated channel subfamily J member 11, GLUD1: glutamate dehydrogenase 1, HADH: hydroxyacyl-CoA dehydrogenase, LAR: long-acting release, IUGR: intrauterine growth restriction, CDG: congenital disorders of glycosylation, SGA: small for gestational age, ${ }^{18} \mathrm{~F}-\mathrm{DOPA}-\mathrm{PET} / \mathrm{CT}$ : ${ }^{18} \mathrm{~F}-$-fluoro-L-dihydroxyphenylalanine-positron emission tomography/computed tomography 


\section{Follow up and Outcome of Congenital Hyperinsulinism}

The management of patients with severe $\mathrm{CHI}$ is challenging and requires a multi-disciplinary team approach which should include clinicians, surgeons, specialized pathologists, geneticists, nurse specialists and dietitians. In studies evaluating the long-term outcome of patients with $\mathrm{HH}$, a high frequency of neurodevelopmental retardation and various neurological disorders, including epilepsy and microcephaly, have been reported $(187,188,189)$. Severity of the disease (based on maximal diazoxide dose) and early presentation ( $<7$ days following birth) were associated with abnormal neurodevelopment, while gender, underlying genetic etiology or the histopathological form of $\mathrm{HH}$ were not related to the neurological outcome (189). In a recent study evaluating long-term neurodevelopmental outcome of 60 patients with $\mathrm{CHI}$, just under two fifths of cases were shown to be affected with motor deficits $(38.6 \%)$ followed by speech problems $(26.9 \%)$, cognitive deficits (15.8\%) and social-emotional problems $(9.4 \%)$, with no correlation between outcome and genetic background (190). Therefore, neurological development should be closely followed up, regardless of the underlying etiology and histopathological type.

Figure 4 outlines management and follow-up of patients with congenital $\mathrm{HH}$.

\section{Conclusions and Future Directions}

$\mathrm{CHI}$ is the most common cause of severe hypoglycaemia in the newborn and childhood period. The molecular basis of $\mathrm{CHI}$ involves defects in key genes (ABCC8, KCNJ11, GLUD1, GCK, HADH, SLC16A1, HNF1A, HNF4A, UCP2, HK1, PGM1, PMM2 and FOXA2) which regulate insulin secretion. Rapid genetic analysis, imaging with ${ }^{18} \mathrm{~F}-\mathrm{DOPA}-\mathrm{PET} / \mathrm{CT}$ scan, potential new medical therapies and development in surgical techniques have improved the management and outcome of the disease. Further research is needed to identify the underlying molecular basis of $\mathrm{CHI}$, especially in patients who are diazoxide responsve. Novel, routinely available imaging techniques should be developed so that patients all over the world can have access to these facilities.

\section{Ethics}

Peer-review: Internally peer-reviewed.

\section{Authorship Contributions}

Concept: Hüseyin Demirbilek, Khalid Hussain, Design: Hüseyin Demirbilek, Khalid Hussain, Data Collection or Processing: Hüseyin Demirbilek, Khalid Hussain, Analysis or Interpretation: Hüseyin Demirbilek, Khalid Hussain, Literature Research: Hüseyin Demirbilek, Khalid Hussain, Writing: Hüseyin Demirbilek, Khalid Hussain.
Financial Disclosure: The authors declared that this study received no financial support.

\section{References}

1. Aynsley-Green A, Hussain K, Hall J, Saudubray JM, Nihoul-Fékété C, De Lonlay-Debeney P, Brunelle F, Otonkoski T, Thornton P, Lindley KJ.Practical management of hyperinsulinism in infancy. Arch Dis Child Fetal Neonatal Ed 2000;82:F98-F107.

2. Hussain K, Aynsley-Green A. Hyperinsulinism in infancy: understanding the pathophysiology. Int J Biochem Cell Biol 2003;35:1312-1317.

3. Ajala ON, Huffman DM, Ghobrial II. Glucokinase mutation-a rare cause of recurrent hypoglycemia in adults: a case report and literature review. J Community Hosp Intern Med Perspect 2016;6:32983. eCollection 2016

4. Gutgold A, Gross DJ, Glaser B, Szalat A. Diagnosis of ABCC8 Congenital Hyperinsulinism of Infancy in a 20-Year-Old Man Evaluated for Factitious Hypoglycemia J Clin Endocrinol Metab 2017;102:345-349.

5. Arya VB, Flanagan SE, Kumaran A, Shield JP, Ellard S, Hussain K, Kapoor RR.Clinical and molecular characterisation of hyperinsulinaemic hypoglycaemia in infants born small-for-gestational age. Arch Dis Child Fetal Neonatal Ed 2013;98:F356-358. Epub 2013 Jan 29

6. Kapoor RR, Flanagan SE, Arya VB, Shield JP, Ellard S, Hussain K. Clinical and molecular characterisation of 300 patients with congenital hyperinsulinism. Eur J Endocrinol 2013;168:557-564. Print 2013 Apr

7. Pierro A, Nah SA. Surgical management of congenital hyperinsulinism of infancy. Semin Pediatr Surg $2011 ; 20: 50-53$.

8. Kapoor RR, Flanagan SE, James C, Shield J, Ellard S, Hussain K. Hyperinsulinaemic hypoglycaemia. Arch Dis Child 2009;94:450-457. Epub 2009 Feb 4

9. Hussain K, Aynsley-Green A. Management of hyperinsulinism in infancy and childhood. Ann Med 2000;32:544-551.

10. James C, Kapoor RR, Ismail D, Hussain K. The genetic basis of congenital hyperinsulinism. J Med Genet 2009;46:289-299. Epub 2009 Mar 1

11. Meintjes M, Endozo R, Dickson J, Erlandsson K, Hussain K, Townsend C, Menezes L, Bomanji J. 18F-DOPA PET and enhanced CT imaging for congenital hyperinsulinism: initial UK experience from a technologist's perspective. Nucl Med Commun 2013;34:601-608.

12. Ismail D, Hussain K. Role of 18F-DOPA PET/CT imaging in congenital hyperinsulinism. Rev Endocr Metab Disord 2010;11:165-169.

13. Kapoor RR, Heslegrave A, Hussain K.Congenital hyperinsulinism due to mutations in HNF4A and HADH. Rev Endocr Metab Disord 2010;11:185 191

14. Flanagan SE, Kapoor RR, Hussain K. Genetics of congenital hyperinsulinemic hypoglycemia. Semin Pediatr Surg 2011;20:13-17

15. Ackermann AM LC, Freeze HH, Ficicioglu C, Kaestner KH, Stanley CA. Hypoglycemia due to lower threshold of glucose-stimulated insulin secretion in phosphoglucomutase 1 deficiency. Platform Presentation at: Annual Meeting of the Pediatric Academic Societies, April 25-28, 2015; San Diego, CA.

16. Cabezas OR, Flanagan SE, Stanescu H, García-Martínez E, Caswell R, LangoAllen $\mathrm{H}$, Antón-Gamero M, Argente J, Bussell AM, Brandli A, Cheshire C, Crowne E, Dumitriu S, Drynda R, Hamilton-Shield JP, Hayes W, Hofherr A, Iancu D, Issler N, Jefferies C, Jones P, Johnson M, Kesselheim A, Klootwijk E, Koettgen M, Lewis W, Martos JM, Mozere M, Norman J, Patel V, Parrish A, Pérez-Cerdá C, Pozo J, Rahman SA, Sebire N, Tekman M, Turnpenny PD, Hoff WV, Viering DHHM, Weedon MN, Wilson P, Guay-Woodford L, Kleta R, Hussain K, Ellard S, Bockenhauer D. Polycystic Kidney Disease with Hyperinsulinemic Hypoglycemia Caused by a Promoter Mutation in Phosphomannomutase 2. J Am Soc Nephrol 2017;28:2529-2539. Epub 2017 Apr 3

17. Pinney SE, Ganapathy K, Bradfield J, Stokes D, Sasson A, Mackiewicz K, Boodhansingh K, Hughes N, Becker S, Givler S, Macmullen C, Monos D, Ganguly A, Hakonarson H, Stanley CA. Dominant form of congenital hyperinsulinism maps to HK1 region on 10q. Horm Res Paediatr 2013;80:18-27. Epub 2013 Jul 13 
18. Tegtmeyer LC, Rust S, van Scherpenzeel M, Ng BG, Losfeld ME, Timal S, Raymond K, He P, Ichikawa M, Veltman J, Huijben K, Shin YS, Sharma V, Adamowicz M, Lammens M, Reunert J, Witten A, Schrapers E, Matthijs G, Jaeken J, Rymen D, Stojkovic T, Laforêt P, Petit F, Aumaître O, Czarnowska E, Piraud M, Podskarbi T, Stanley CA, Matalon R, Burda P, Seyyedi S, Debus V, Socha P, Sykut-Cegielska J, van Spronsen F, de Meirleir L, Vajro P, DeClue T, Ficicioglu C, Wada Y, Wevers RA, Vanderschaeghe D, Callewaert $N$, Fingerhut R, van Schaftingen E, Freeze HH, Morava E, Lefeber DJ, Marquardt T. Multiple phenotypes in phosphoglucomutase 1 deficiency. $\mathrm{N}$ Engl J Med 2014;370:533-542.

19. Giri D, Vignola ML, Gualtieri A, Scagliotti V, McNamara P, Peak M, Didi M, Gaston-Massuet C, Senniappan S. Novel FOXA2 mutation causes Hyperinsulinism, Hypopituitarism with Craniofacial and Endodermderived organ abnormalities. Hum Mol Genet 2017;26:4315-4326.

20. Flanagan SE, Vairo F, Johnson MB, Caswell R, Laver TW, Lango Allen H, Hussain K, Ellard S. A CACNA1D mutation in a patient with persistent hyperinsulinaemic hypoglycaemia, heart defects, and severe hypotonia. Pediatr Diabetes 2017;18:320-323. Epub 2017 Mar 20

21. Malaisse WJ, Sener A, Herchuelz A, Hutton JC. Insulin release: the fuel hypothesis. Metabolism 1979;28:373-386.

22. Dunne MJ, Cosgrove KE, Shepherd RM, Aynsley-Green A, Lindley KJ. Hyperinsulinism in infancy: from basic science to clinical disease. Physiol Rev 2004;84:239-275.

23. Johnson JH, Newgard CB, Milburn JL, Lodish HF, Thorens B.The high Km glucose transporter of islets of Langerhans is functionally similar to the low affinity transporter of liver and has an identical primary sequence. J Biol Chem 1990;265:6548-6551.

24. Gould GW, Thomas HM, Jess TJ, Bell GI. Expression of human glucose transporters in Xenopus oocytes: kinetic characterization and substrate specificities of the erythrocyte, liver, and brain isoforms. Biochemistry 1991;30:5139-5145.

25. Matschinsky FM. Banting Lecture 1995. A lesson in metabolic regulation inspired by the glucokinase glucose sensor paradigm. Diabetes 1996;45:223-241.

26. Cryer PE. Glucose counterregulation: prevention and correction of hypoglycemia in humans. Am J Physiol 1993;264:E149-155.

27. Cryer PE, Axelrod L, Grossman AB, Heller SR, Montori VM, Seaquist ER, Service FJ; Endocrine Society. Evaluation and management of adult hypoglycemic disorders: an Endocrine Society Clinical Practice Guideline. J Clin Endocrinol Metab 2009;94:709-728. Epub 2008 Dec 16

28. Ferrara CT, Boodhansingh KE, Paradies E, Giuseppe F, Steinkrauss LJ, Topor LS, Quintos JB, Ganguly A, De Leon DD, Palmieri F, Stanley CA. Novel Hypoglycemia Phenotype in Congenital Hyperinsulinism Due to Dominant Mutations of Uncoupling Protein 2. J Clin Endocrinol Metab 2017;102:942949.

29. Ferrara C, Patel P, Becker S, Stanley CA, Kelly A. Biomarkers of Insulin for the Diagnosis of Hyperinsulinemic Hypoglycemia in Infants and Children. J Pediatr 2016;168:212-219. Epub 2015 Oct 17

30. Brady C, Palladino AA, Gutmark-Little I. A novel case of compound heterozygous congenital hyperinsulinism without high insulin levels. Int J Pediatr Endocrinol 2015;2015:16. Epub 2015 Jul 15

31. Palladino AA, Bennett MJ, Stanley CA. Hyperinsulinism in infancy and childhood: when an insulin level is not always enough. Clin Chem 2008;54:256-263. Epub 2007 Dec 21

32. Senniappan S, Shanti B, James C, Hussain K. Hyperinsulinaemic hypoglycaemia: genetic mechanisms, diagnosis and management. J Inherit Metab Dis 2012;35:589-601. Epub 2012 Jan 10

33. Shah $P$, Rahman SA, Demirbilek H, Güemes M, Hussain $K$. Hyperinsulinaemic hypoglycaemia in children and adults. Lancet Diabetes Endocrinol 2017;5:729-742. Epub 2016 Dec 1

34. Stanley CA, Lieu YK, Hsu BY, Burlina AB, Greenberg CR, Hopwood NJ, Perlman K, Rich BH, Zammarchi E, Poncz M. Hyperinsulinism and hyperammonemia in infants with regulatory mutations of the glutamate dehydrogenase gene. N Engl J Med 1998;338:1352-1357.

35. Clayton PT, Eaton S, Aynsley-Green A, Edginton M, Hussain K, Krywawych $S$, Datta V, Malingre HE, Berger R, van den Berg IE. Hyperinsulinism in short-chain L-3-hydroxyacyl-CoA dehydrogenase deficiency reveals the importance of beta-oxidation in insulin secretion. J Clin Invest 2001;108:457-465.

36. Hsu BY, Kelly A, Thornton PS, Greenberg CR, Dilling LA, Stanley CA. Proteinsensitive and fasting hypoglycemia in children with the hyperinsulinism/ hyperammonemia syndrome. J Pediatr 2001;138:383-389.

37. Meissner T, Otonkoski T, Feneberg R, Beinbrech B, Apostolidou S, Sipilä I, Schaefer F, Mayatepek E. Exercise induced hypoglycaemic hyperinsulinism. Arch Dis Child 2001;84:254-257.

38. Otonkoski T, Kaminen N, Ustinov J, Lapatto R, Meissner T, Mayatepek E, Kere J, Sipilä I. Physical exercise-induced hyperinsulinemic hypoglycemia is an autosomal-dominant trait characterized by abnormal pyruvateinduced insulin release. Diabetes 2003;52:199-204.

39. Finegold DN, Stanley CA, Baker L. Glycemic response to glucagon during fasting hypoglycemia: an aid in the diagnosis of hyperinsulinism. J Pediatr 1980;96:257-259.

40. Levitt Katz LE, Satin-Smith MS, Collett-Solberg P, Thornton PS, Baker L, Stanley CA, Cohen P.Insulin-like growth factor binding protein-1 levels in the diagnosis of hypoglycemia caused by hyperinsulinism. J Pediatr 1997;131:193-199.

41. Fafoula O, Alkhayyat H, Hussain K. Prolonged hyperinsulinaemic hypoglycaemia in newborns with intrauterine growth retardation. Arch Dis Child Fetal Neonatal Ed 2006;91:F467.

42. Yap F, Högler W, Vora A, Halliday R, Ambler G. Severe transient hyperinsulinaemic hypoglycaemia: two neonates without predisposing factors and a review of the literature. Eur J Pediatr 2004;163:38-41. Epub 2003 Oct 29

43. Gribble FM, Reimann F. Sulphonylurea action revisited: the post-cloning era. Diabetologia 2003;46:875-891. Epub 2003 Jun 18

44. Ashcroft FM, Gribble FM.New windows on the mechanism of action of K(ATP) channel openers. Trends Pharmacol Sci 2000;21:439-445.

45. Rajan AS, Aguilar-Bryan L, Nelson DA, Nichols CG, Wechsler SW, Lechago $J$, Bryan J. Sulfonylurea receptors and ATP-sensitive $\mathrm{K}+$ channels in clonal pancreatic alpha cells. Evidence for two high affinity sulfonylurea receptors. J Biol Chem 1993;268:15221-15228.

46. Shimono D, Fujimoto S, Mukai E, Takehiro M, Nabe K, Radu RG, Shimodahira M, Kominato R, Aramaki Y, Nishi Y, Funakoshi S, Yamada Y, Seino Y. ATP enhances exocytosis of insulin secretory granules in pancreatic islets under $\mathrm{Ca} 2+$-depleted condition. Diabetes Res Clin Pract 2005;69:216-223. Epub 2005 Mar 21

47. Karaca M, Frigerio F, Maechler P. From pancreatic islets to central nervous system, the importance of glutamate dehydrogenase for the control of energy homeostasis. Neurochem Int 2011;59:510-517. Epub 2011 May 12

48. Maechler P. Glutamate pathways of the beta-cell and the control of insulin secretion. Diabetes Res Clin Pract 2017;131:149-153. Epub 2017 Jul 12

49. Thomas PM, Cote GJ, Wohllk N, Haddad B, Mathew PM, Rabl W, AguilarBryan L, Gagel RF, Bryan J. Mutations in the sulfonylurea receptor gene in familial persistent hyperinsulinemic hypoglycemia of infancy. Science 1995;268:426-429.

50. Thomas P, Ye Y, Lightner E. Mutation of the pancreatic islet inward rectifier Kir6.2 also leads to familial persistent hyperinsulinemic hypoglycemia of infancy. Hum Mol Genet 1996;5:1809-1812.

51. Lord K, Dzata E, Snider KE, Gallagher PR, De León DD. Clinical presentation and management of children with diffuse and focal hyperinsulinism: a review of 223 cases. J Clin Endocrinol Metab 2013;98:E1786-1789. Epub 2013 Sep 20

52. Snider KE, Becker S, Boyajian L, Shyng SL, MacMullen C, Hughes N, Ganapathy K, Bhatti T, Stanley CA, Ganguly A. Genotype and phenotype correlations in 417 children with congenital hyperinsulinism. J Clin Endocrinol Metab 2013;98:E355-363. Epub 2012 Dec 28

53. Pinney SE, MacMullen C, Becker S, Lin YW, Hanna C, Thornton P, Ganguly A, Shyng SL, Stanley CA. Clinical characteristics and biochemical mechanisms of congenital hyperinsulinism associated with dominant KATP channel mutations. J Clin Invest 2008;118:2877-2886.

54. Arya VB, Guemes M, Nessa A, Alam S, Shah P, Gilbert C, Senniappan S, Flanagan SE, Ellard S, Hussain K. Clinical and histological heterogeneity 
of congenital hyperinsulinism due to paternally inherited heterozygous ABCC8/KCNJ11 mutations. Eur J Endocrinol 2014;171:685-695. Epub 2014 Sep 8

55. Rozenkova K, Nessa A, Obermannova B, Elblova L, Dusatkova P, Sumnik Z, Lebl J, Hussain K, Pruhova S. Could a combination of heterozygous ABCC8 and KCNJ11 mutations cause congenital hyperinsulinism? J Pediatr Endocrinol Metab 2017;30:1311-1315.

56. Kelly A, Ng D, Ferry RJ Jr, Grimberg A, Koo-McCoy S, Thornton PS, Stanley $\mathrm{CA}$. Acute insulin responses to leucine in children with the hyperinsulinism/ hyperammonemia syndrome. J Clin Endocrinol Metab 2001;86:37243728.

57. Li C, Najafi H, Daikhin Y, Nissim IB, Collins HW, Yudkoff M, Matschinsky FM, Stanley CA. Regulation of leucine-stimulated insulin secretion and glutamine metabolism in isolated rat islets. J Biol Chem 2003;278:28532858. Epub 2002 Nov 19

58. Kibbey RG, Choi CS, Lee HY, Cabrera O, Pongratz RL, Zhao X, Birkenfeld AL, Li C, Berggren PO, Stanley C, Shulman GI. Mitochondrial GTP insensitivity contributes to hypoglycemia in hyperinsulinemia hyperammonemia by inhibiting glucagon release. Diabetes 2014;63:4218-4229. Epub 2014 Jul 14

59. Stanley CA, Fang J, Kutyna K, Hsu BY, Ming JE, Glaser B, Poncz M.Molecular basis and characterization of the hyperinsulinism/hyperammonemia syndrome: predominance of mutations in exons 11 and 12 of the glutamate dehydrogenase gene. HI/HA Contributing Investigators. Diabetes 2000;49:667-673.

60. Weinzimer SA, Stanley CA, Berry GT, Yudkoff M, Tuchman M, Thornton PS. A syndrome of congenital hyperinsulinism and hyperammonemia. J Pediatr 1997;130:661-664.

61. Meissner T, Mayatepek E, Kinner M, Santer R. Urinary alpha-ketoglutarate is elevated in patients with hyperinsulinism-hyperammonemia syndrome. Clin Chim Acta 2004;341:23-26.

62. Agren A, Borg K, Brolin SE, Carlman J, Lundqvist G. Hydroxyacyl CoA dehydrogenase, an enzyme important in fat metabolism in different cell types in the islets of Langerhans. Diabete Metab 1977;3:169-172.

63. Li C, Chen P, Palladino A, Narayan S, Russell LK, Sayed S, Xiong G, Chen J, Stokes D, Butt YM, Jones PM, Collins HW, Cohen NA, Cohen AS, Nissim I, Smith TJ, Strauss AW, Matschinsky FM, Bennett MJ, Stanley CA. Mechanism of hyperinsulinism in short-chain 3-hydroxyacyl-CoA dehydrogenase deficiency involves activation of glutamate dehydrogenase. J Biol Chem 20108;285:31806-31818. Epub 2010 Jul 29

64. Heslegrave AJ, Kapoor RR, Eaton S, Chadefaux B, Akcay T, Simsek E, Flanagan SE, Ellard S, Hussain K. Leucine-sensitive hyperinsulinaemic hypoglycaemia in patients with loss of function mutations in 3-HydroxyacylCoA Dehydrogenase. Orphanet J Rare Dis 2012;7:25.

65. Molven A, Matre GE, Duran M, Wanders RJ, Rishaug U, Njølstad PR, Jellum E, Søvik O. Familial hyperinsulinemic hypoglycemia caused by a defect in the SCHAD enzyme of mitochondrial fatty acid oxidation. Diabetes 2004;53:221-227.

66. Heslegrave AJ, Hussain K. Novel insights into fatty acid oxidation, amino acid metabolism, and insulin secretion from studying patients with loss of function mutations in 3-hydroxyacyl-CoA dehydrogenase. J Clin Endocrinol Metab 2013;98:496-501. Epub 2012 Dec 18

67. Babiker O, Flanagan SE, Ellard S, Al Girim H, Hussain K, Senniappan S. Protein-induced hyperinsulinaemic hypoglycaemia due to a homozygous HADH mutation in three siblings of a Saudi family. J Pediatr Endocrinol Metab 2015;28:1073-1077.

68. Flanagan SE, Patch AM, Locke JM, Akcay T, Simsek E, Alaei M, Yekta Z, Desai M, Kapoor RR, Hussain K, Ellard S. Genome-wide homozygosity analysis reveals HADH mutations as a common cause of diazoxideresponsive hyperinsulinemic-hypoglycemia in consanguineous pedigrees. J Clin Endocrinol Metab 2011;96:E498-502. Epub 2011 Jan 20

69. Iynedjian PB, Pilot PR, Nouspikel T, Milburn JL, Quaade C, Hughes S, Ucla $\mathrm{C}$, Newgard CB. Differential expression and regulation of the glucokinase gene in liver and islets of Langerhans. Proc Natl Acad Sci USA 1989;86:78387842 .
70. Matschinsky FM. Regulation of pancreatic beta-cell glucokinase: from basics to therapeutics. Diabetes 2002;51 (Suppl 3):S394-404.

71. Kukuvitis A, Deal C, Arbour L, Polychronakos C. An autosomal dominant form of familial persistent hyperinsulinemic hypoglycemia of infancy, not linked to the sulfonylurea receptor locus. J Clin Endocrinol Metab 1997;82:1192-1194.

72. Martínez R, Gutierrez-Nogués Á, Fernández-Ramos C, Velayos T, Vela A; Spanish Congenital Hyperinsulinism Group, Navas MÁ, Castaño L. Heterogeneity in phenotype of hyperinsulinism caused by activating glucokinase mutations: a novel mutation and its functional characterization. Clin Endocrinol (Oxf) 2017;86:778-783. Epub 2017 Mar 27

73. Barbetti F, Cobo-Vuilleumier N, Dionisi-Vici C, Toni S, Ciampalini P, Massa O, Rodriguez-Bada P, Colombo C, Lenzi L, Garcia-Gimeno MA, Bermudez-Silva FJ, Rodriguez de Fonseca F, Banin P, Aledo JC, Baixeras E, Sanz P, Cuesta-Muñoz AL. Opposite clinical phenotypes of glucokinase disease: Description of a novel activating mutation and contiguous inactivating mutations in human glucokinase (GCK) gene. Mol Endocrinol 2009;23:1983-1989. Epub 2009 Nov 2

74. Morishita K, Kyo C, Yonemoto T, Kosugi R, Ogawa T, Inoue T. Asymptomatic Congenital Hyperinsulinism due to a Glucokinase-Activating Mutation, Treated as Adrenal Insufficiency for Twelve Years. Case Rep Endocrinol 2017;2017:4709262. Epub 2017 Jan 9

75. Cuesta-Muñoz AL, Huopio H, Otonkoski T, Gomez-Zumaquero JM, NäntöSalonen K, Rahier J, López-Enriquez S, García-Gimeno MA, Sanz P, Soriguer FC, Laakso M.Severe persistent hyperinsulinemic hypoglycemia due to a de novo glucokinase mutation. Diabetes 2004;53:2164-2168.

76. Pullen TJ, Sylow L, Sun G, Halestrap AP, Richter EA, Rutter GA. Overexpression of monocarboxylate transporter-1 (SLC16A1) in mouse pancreatic $\beta$-cells leads to relative hyperinsulinism during exercise. Diabetes 2012;61:1719-1725. Epub 2012 Apr 20

77. Miura A, Yamagata K, Kakei M, Hatakeyama H, Takahashi N, Fukui K, Nammo T, Yoneda K, Inoue Y, Sladek FM, Magnuson MA, Kasai H, Miyagawa J, Gonzalez FJ, Shimomura I. Hepatocyte nuclear factor-4alpha is essential for glucose-stimulated insulin secretion by pancreatic beta-cells. J Biol Chem 2006;281:5246-5257. Epub 2005 Dec 23

78. Taraviras S, Monaghan AP, Schütz G, Kelsey G. Characterization of the mouse HNF-4 gene and its expression during mouse embryogenesis. Mech Dev 1994;48:67-79.

79. Pearson ER, Boj SF, Steele AM, Barrett T, Stals K, Shield JP, Ellard S, Ferrer J, Hattersley AT. Macrosomia and hyperinsulinaemic hypoglycaemia in patients with heterozygous mutations in the HNF4A gene. PLoS Med 2007;4:e118.

80. Yamagata K, Furuta H, Oda N, Kaisaki PJ, Menzel S, Cox NJ, Fajans SS, Signorini S, Stoffel M, Bell GI. sMutations in the hepatocyte nuclear factor4alpha gene in maturity-onset diabetes of the young (MODY1). Nature 1996;384:458-460.

81. Yamagata K, Oda N, Kaisaki PJ, Menzel S, Furuta H, Vaxillaire M, Southam L, Cox RD, Lathrop GM, Boriraj VV, Chen X, Cox NJ, Oda Y, Yano H, Le Beau MM, Yamada S, Nishigori H, Takeda J, Fajans SS, Hattersley AT, Iwasaki N, Hansen T, Pedersen O, Polonsky KS, Bell GI. Mutations in the hepatocyte nuclear factor-1alpha gene in maturity-onset diabetes of the young (MODY3). Nature 1996;384:455-458.

82. Arya VB, Rahman S, Senniappan S, Flanagan SE, Ellard S, Hussain K. HNF4A mutation: switch from hyperinsulinaemic hypoglycaemia to maturity-onset diabetes of the young, and incretin response. Diabet Med 2014;31:e11-15.

83. Fajans SS, Bell GI. HNF4A mutation: switch from hyperinsulinaemic hypoglycaemia to maturity-onset diabetes of the young, and incretin response. Diabetologia 2007;50:2600-2601. Epub 2007 Sep 22

84. Flanagan SE, Kapoor RR, Mali G, Cody D, Murphy N, Schwahn B, Siahanidou T, Banerjee I, Akcay T, Rubio-Cabezas O, Shield JP, Hussain K, Ellard S. Diazoxide-responsive hyperinsulinemic hypoglycemia caused by HNF4A gene mutations. Eur J Endocrinol 2010;162:987-992. Epub 2010 Feb 17 
85. Kapoor RR, Locke J, Colclough K, Wales J, Conn JJ, Hattersley AT, Ellard S, Hussain K. Persistent hyperinsulinemic hypoglycemia and maturity-onset diabetes of the young due to heterozygous HNF4A mutations. Diabetes 2008;57:1659-1663. Epub 2008 Feb 11

86. Stanik J, Skopkova M, Brennerova K, Danis D, Rosolankova M, Salingova A, Bzduch V, Klimes I, Gasperikova D. Congenital hyperinsulinism and glycogenosis-like phenotype due to a novel HNF4A mutation. Diabetes Res Clin Pract 2017;126:144-150. Epub 2017 Feb 16

87. Stanescu DE, Hughes N, Kaplan B, Stanley CA, De León DD. Novel presentations of congenital hyperinsulinism due to mutations in the MODY genes: HNF1A and HNF4A. J Clin Endocrinol Metab 2012;97:E2026-2030. Epub 2012 Jul 16

88. Rozenkova K, Malikova J, Nessa A, Dusatkova L, Bjørkhaug L, Obermannova B, Dusatkova P, Kytnarova J, Aukrust I, Najmi LA, Rypackova B, Sumnik Z, Lebl J, Njølstad PR, Hussain K, Pruhova S. High Incidence of Heterozygous ABCC 8 and HNF1A Mutations in Czech Patients With Congenital Hyperinsulinism. J Clin Endocrinol Metab 2015;100:E1540-1549. Epub 2015 Oct 2

89. Fleury C, Neverova M, Collins S, Raimbault S, Champigny O, Levi-Meyrueis C, Bouillaud F, Seldin MF, Surwit RS, Ricquier D, Warden CH. Uncoupling protein-2: a novel gene linked to obesity and hyperinsulinemia. Nat Genet 1997;15:269-272.

90. González-Barroso MM, Giurgea I, Bouillaud F, Anedda A, Bellanné-Chantelot C, Hubert L, de Keyzer Y, de Lonlay P, Ricquier D. Mutations in UCP2 in congenital hyperinsulinism reveal a role for regulation of insulin secretion. PLoS One 2008;3:e3850. Epub 2008 Dec 9

91. Krauss S, Zhang CY, Lowell BB. A significant portion of mitochondrial proton leak in intact thymocytes depends on expression of UCP2. Proc Natl Acad Sci USA 2002;99:11 8-122. Epub 2001 Dec 26

92. Chan CB, De Leo D, Joseph JW, McQuaid TS, Ha XF, Xu F, Tsushima RG, Pennefather PS, Salapatek AM, Wheeler MB. Increased uncoupling protein-2 levels in beta-cells are associated with impaired glucose-stimulated insulin secretion: mechanism of action. Diabetes 2001;50:1302-1310.

93. Mcquarrie I. Idiopathic spontaneously occurring hypoglycemia in infants; clinical significance of problem and treatment. AMA Am J Dis Child 1954:87:399-428.

94. Laver TW, Weedon MN, Caswell R, Hussain K, Ellard S, Flanagan SE. Analysis of large-scale sequencing cohorts does not support the role of variants in UCP2 as a cause of hyperinsulinaemic hypoglycaemia. Hum Mutat 2017;38:1442-1444. Epub 2017 Aug 1

95. Henquin JC, Sempoux C, Marchandise J, Godecharles S, Guiot Y, Nenquin $\mathrm{M}$, Rahier J.Congenital hyperinsulinism caused by hexokinase I expression or glucokinase-activating mutation in a subset of $\beta$-cells. Diabetes 2013;62:1689-1696. Epub 2012 Dec 28

96. Hussain K. Diagnosis and management of hyperinsulinaemic hypoglycaemia of infancy. Horm Res 2008;69:2-13. Epub 2007 Dec 4

97. Goldfine AB, Mun EC, Devine E, Bernier R, Baz-Hecht M, Jones DB, Schneider BE, Holst JJ, Patti ME. Patients with neuroglycopenia after gastric bypass surgery have exaggerated incretin and insulin secretory responses to a mixed meal. J Clin Endocrinol Metab 2007;92:4678-4685. Epub 2007 Sep 25

98. Neylon OM, Moran MM, Pellicano A, Nightingale M, O'Connell MA. Successful subcutaneous glucagon use for persistent hypoglycaemia in congenital hyperinsulinism. J Pediatr Endocrinol Metab 2013;26:11571161.

99. Mohnike K, Blankenstein O, Pfuetzner A, Pötzsch S, Schober E, Steiner S, Hardy OT, Grimberg A, van Waarde WM. Long-term non-surgical therapy of severe persistent congenital hyperinsulinism with glucagon. Horm Res 2008;70:59-64. Epub 2008 May 21

100. Banerjee I, Forsythe L, Skae M, Avatapalle HB, Rigby L, Bowden LE, Craigie R, Padidela R, Ehtisham S, Patel L, Cosgrove KE, Dunne MJ, Clayton PE. Feeding Problems Are Persistent in Children with Severe Congenital Hyperinsulinism. Front Endocrinol (Lausanne) 20169;7:8. eCollection 2016

101. Al-Shanafey S, Alkhudhur H. Food aversion among patients with persistent hyperinsulinemic hypoglycemia of infancy. J Pediatr Surg 2012;47:895897.
102. Welters A, Lerch C, Kummer S, Marquard J, Salgin B, Mayatepek E, Meissner T. Long-term medical treatment in congenital hyperinsulinism: a descriptive analysis in a large cohort of patients from different clinical centers. Orphanet J Rare Dis 2015;10:150.

103. Maiorana A, Barbetti F, Boiani A, Rufini V, Pizzoferro M, Francalanci P, Faletra F, Nichols CG, Grimaldi C, de Ville de Goyet J, Rahier J, Henquin JC, Dionisi-Vici C. Focal congenital hyperinsulinism managed by medical treatment: a diagnostic algorithm based on molecular genetic screening. Clin Endocrinol (Oxf) 2014;81:679-688. Epub 2014 Jan 30

104. Lord K, De León DD. Monogenic hyperinsulinemic hypoglycemia: current insights into the pathogenesis and management. Int J Pediatr Endocrinol 2013;2013:3.

105. Nebesio TD, Hoover WC, Caldwell RL, Nitu ME, Eugster EA. Development of pulmonary hypertension in an infant treated with diazoxide. J Pediatr Endocrinol Metab 2007;20:939-944.

106. Yildizdas D, Erdem S, Küçükosmanoglu O, Yilmaz M, Yüksel B. Pulmonary hypertension, heart failure and neutropenia due to diazoxide therapy. Adv Ther 2008;25:515-519.

107. Demirel F, Unal S, Çetin II, Esen I, Arasli A.Pulmonary hypertension and reopening of the ductus arteriosus in an infant treated with diazoxide. J Pediatr Endocrinol Metab 2011;24:603-605.

108. Timlin MR, Black AB, Delaney HM, Matos RI, Percival CS. Development of Pulmonary Hypertension During Treatment with Diazoxide: A Case Series and Literature Review. Pediatr Cardiol 2017;38:1247-1250. Epub 2017 Jun 22

109. Arya VB, Mohammed Z, Blankenstein O, De Lonlay P, Hussain K. Hyperinsulinaemic hypoglycaemia. Horm Metab Res 2014;46:157-170. Epub 2014 Feb 20

110. Katz MD, Erstad BL. Octreotide, a new somatostatin analogue. Clin Pharm 1989;8:255-273.

111. Doyle ME, Egan JM. Pharmacological agents that directly modulate insulin secretion. Pharmacol Rev 2003;55:105-131.

112. Yorifuji T, Kawakita R, Hosokawa Y, Fujimaru R, Matsubara K, Aizu K, Suzuki S, Nagasaka H, Nishibori H, Masue M. Efficacy and safety of longterm, continuous subcutaneous octreotide infusion for patients with different subtypes of KATP-channel hyperinsulinism. Clin Endocrinol (Oxf) 2013;78:891-897. Epub 2013 Apr 6

113. Wahid ST, Marbach P, Stolz B, Miller M, James RA, Ball SG. Partial tachyphylaxis to somatostatin (SST) analogues in a patient with acromegaly: the role of SST receptor desensitisation and circulating antibodies to SST analogues. Eur J Endocrinol 2002;146:295-302.

114. Escorsell A, Bandi JC, Andreu V, Moitinho E, Garcia-Pagán JC, Bosch J, Rodés J. Desensitization to the effects of intravenous octreotide in cirrhotic patients with portal hypertension. Gastroenterology 2001;120:161-169.

115. Hawkes CP, Adzick NS, Palladino AA, De León DD. Late Presentation of Fulminant Necrotizing Enterocolitis in a Child with Hyperinsulinism on Octreotide Therapy. Horm Res Paediatr 2016;86:131-136. Epub 2016 Feb 12

116. Levy-Khademi F, Irina S, Avnon-Ziv C, Levmore-Tamir M, Leder O. Octreotide-associated cholestasis and hepatitis in an infant with congenital hyperinsulinism. J Pediatr Endocrinol Metab 2015;28:449-451.

117. Demirbilek H, Shah P, Arya VB, Hinchey L, Flanagan SE, Ellard S, Hussain K. Long-term follow-up of children with congenital hyperinsulinism on octreotide therapy. J Clin Endocrinol Metab 2014;99:3660-3667. Epub 2014 Jun 17

118. Celik N, Cinaz P, Emeksiz HC, Hussain K, Çamurdan O, Bideci A, Döğer E, Yüce Ö, Türkyılmaz Z, Oğuz AD. Octreotide-induced long QT syndrome in a child with congenital hyperinsulinemia and a novel missense mutation (p.Met115Val) in the ABCC8 gene. Horm Res Paediatr 2013;80:299-303. Epub 2013 Sep 27

119. Koren I, Riskin A, Barthlen W, Gillis D. Hepatitis in an infant treated with octreotide for congenital hyperinsulinism. J Pediatr Endocrinol Metab 2013;26:183-185.

120. Harris AG. Somatostatin and somatostatin analogues: pharmacokinetics and pharmacodynamic effects. Gut 1994;35(Suppl 3):S1-4. 
121. McMahon AW, Wharton GT, Thornton P, De Leon DD. Octreotide use and safety in infants with hyperinsulinism. Pharmacoepidemiol Drug Saf 2017;26:26-31. Epub 2016 Dec 2

122. Hawkes CP, Adzick NS, Palladino AA, De León DD. Late Presentation of Fulminant Necrotizing Enterocolitis in a Child with Hyperinsulinism on Octreotide Therapy. Horm Res Paediatr 2016;86:131-136. Epub 2016 Feb 12

123. Hosokawa Y, Kawakita R, Yokoya S, Ogata T, Ozono K, Arisaka O, Hasegawa Y, Kusuda S, Masue M, Nishibori H, Sairenchi T, Yorifuji T. Efficacy and safety of octreotide for the treatment of congenital hyperinsulinism: a prospective, open-label clinical trial and an observational study in Japan using a nationwide registry. Endocr J 2017;64:867-880. Epub 2017 Jul 11

124. Petersen H, Bizec JC, Schuetz H, Delporte ML. Pharmacokinetic and technical comparison of Sandostatin ${ }^{\circledR}$ LAR $^{\circledR}$ and other formulations of long-acting octreotide. BMC Res Notes 201;4:344.

125. Shah P, Rahman SA, McElroy S, Gilbert C, Morgan K, Hinchey L, Senniappan S, Levy H, Amin R, Hussain K. Use of Long-Acting Somatostatin Analogue (Lanreotide) in an Adolescent with Diazoxide-Responsive Congenital Hyperinsulinism and Its Psychological Impact. Horm Res Paediatr 2015;84:355-360. Epub 2015 Sep 17

126. Kühnen P, Marquard J, Ernert A, Meissner T, Raile K, Wannenmacher $\mathrm{G}$, Blankenstein $\mathrm{O}$. Long-term lanreotide treatment in six patients with congenital hyperinsulinism. Horm Res Paediatr 2012;78:106-112. Epub 2012 Aug 14

127. Modan-Moses D, Koren I, Mazor-Aronovitch K, Pinhas-Hamiel O, Landau $\mathrm{H}$. Treatment of congenital hyperinsulinism with lanreotide acetate (Somatuline Autogel). J Clin Endocrinol Metab 2011;96:2312-2317. Epub 2011 Jun 22

128. Al-Zubeidi H, Gottschalk ME, Newfield RS. Successful use of long acting octreotide in two cases with Beckwith-Wiedemann syndrome and severe hypoglycemia. Int J Pediatr Endocrinol 2014;2014:18. Epub 2014 Sep 15

129. Le Quan Sang KH, Arnoux JB, Mamoune A, Saint-Martin C, BellannéChantelot C, Valayannopoulos V, Brassier A, Kayirangwa H, Barbier V, Broissand C, Fabreguettes JR, Charron B, Thalabard JC, de Lonlay P. Successful treatment of congenital hyperinsulinism with long-acting release octreotide. Eur J Endocrinol 2012;166:333-339. Epub 2011 Nov 2

130. Corda H, Kummer S, Welters A, Teig N, Klee D, Mayatepek E, Meissner T. Treatment with long-acting lanreotide autogel in early infancy in patients with severe neonatal hyperinsulinism. Orphanet J Rare Dis 2017;12:108.

131. Giri D, Price V, Yung Z, Didi M, Senniappan S. Fluoxetine-Induced Hypoglycaemia in a Patient with Congenital Hyperinsulinism on Lanreotide Therapy. J Clin Res Pediatr Endocrinol 2016;8:347-350. Epub 2016 Apr 18

132. Mergler S, Singh V, Grötzinger C, Kaczmarek P, Wiedenmann B, Strowski MZ. Characterization of voltage operated R-type $\mathrm{Ca} 2+$ channels in modulating somatostatin receptor subtype 2- and 3-dependent inhibition of insulin secretion from INS-1 cells. Cell Signal 2008;20:2286-2295. Epub 2008 Aug 28

133. Baș F, Darendeliler F, Demirkol D, Bundak R, Saka N, Günöz H. Successful therapy with calcium channel blocker (nifedipine) in persistent neonatal hyperinsulinemic hypoglycemia of infancy. J Pediatr Endocrinol Metab 1999;12:873-878.

134. Durmaz E, Flanagan SE, Parlak M, Ellard S, Akcurin S, Bircan I.A combination of nifedipine and octreotide treatment in an hyperinsulinemic hypoglycemic infant. J Clin Res Pediatr Endocrinol 2014;6:11 9-121.

135. Suprasongsin C, Suthutvoravut U, Mahachoklertwattana P, Preeyasombat C. Combined raw cornstarch and nifedipine as an additional treatment in persistent hyperinsulinemic hypoglycemia of infancy. J Med Assoc Thai 1999;82(Suppl 1):S39-42.

136. Eichmann D, Hufnagel M, Quick P, Santer R. Treatment of hyperinsulinaemic hypoglycaemia with nifedipine. Eur J Pediatr 1999;158:204-206.

137. Khawash P, Hussain K, Flanagan SE, Chatterjee S, Basak D. Nifedipine in Congenital Hyperinsulinism - A Case Report. J Clin Res Pediatr Endocrinol 2015;7:151-154.

138. Shanbag P, Pathak A, Vaidya M, Shahid SK. Persistent hyperinsulinemic hypoglycemia of infancy--successful therapy with nifedipine. Indian J Pediatr 2002;69:271-272.
139. Güemes M, Shah P, Silvera S, Morgan K, Gilbert C, Hinchey L, Hussain K. Assessment of Nifedipine Therapy in Hyperinsulinemic Hypoglycemia due to Mutations in the ABCC8 Gene. J Clin Endocrinol Metab 2017;102:822830.

140. Yang SB, Lee HY, Young DM, Tien AC, Rowson-Baldwin A, Shu YY, Jan YN, Jan LY. Rapamycin induces glucose intolerance in mice by reducing islet mass, insulin content, and insulin sensitivity. J Mol Med (Berl) 2012;90:575-585. Epub 2011 Nov 22

141. Wullschleger S, Loewith R, Oppliger W, Hall MN. Molecular organization of target of rapamycin complex 2. J Biol Chem 2005;280:30697-30704. Epub 2005 Jul 7

142. Meyuhas O. Synthesis of the translational apparatus is regulated at the translational level. Eur J Biochem 2000;267:6321-6330.

143. Alexandrescu S, Tatevian N, Olutoye O, Brown RE. Persistent hyperinsulinemic hypoglycemia of infancy: constitutive activation of the mTOR pathway with associated exocrine-islet transdifferentiation and therapeutic implications Int J Clin Exp Pathol 2010;3:691-705.

144. Wullschleger S, Loewith R, Hall MN. TOR signaling in growth and metabolism. Cell 2006;124:471-484.

145. Leibiger IB, Leibiger B, Moede T, Berggren PO. Exocytosis of insulin promotes insulin gene transcription via the insulin receptor/PI-3 kinase/ p70 s6 kinase and CaM kinase pathways. Mol Cell 1998;1:933-938.

146. Newman JC, Verdin E. Ketone bodies as signaling metabolites. Trends Endocrinol Metab 2014;25:42-52. Epub 2013 Oct 18

147. Senniappan S, Alexandrescu S, Tatevian N, Shah P, Arya V, Flanagan S, Ellard S, Rampling D, Ashworth M, Brown RE, Hussain K. Sirolimus therapy in infants with severe hyperinsulinemic hypoglycemia. N Engl J Med 2014;370:1131-1137.

148. Abraham MB, Shetty VB, Price G, Smith N, Bock Md, Siafarikas A, Resnick S, Whan E, Ellard S, Flanagan SE, Davis EA, Jones TW, Hussain K, Choong CS. Efficacy and safety of sirolimus in a neonate with persistent hypoglycaemia following near-total pancreatectomy for hyperinsulinaemic hypoglycaemia. J Pediatr Endocrinol Metab 2015;28:1391-1398.

149. Minute M, Patti G, Tornese G, Faleschini E, Zuiani C, Ventura A. Sirolimus Therapy in Congenital Hyperinsulinism: A Successful Experience Beyond Infancy. Pediatrics 2015;136:e1373-1376.

150. Ünal S, Gönülal D, Uçaktürk A, Siyah Bilgin B, Flanagan SE, Gürbüz F, Tayfun M, Elmaoğulları S, Arash A, Demirel F, Ellard S, Hussain K. A Novel Homozygous Mutation in the KCNJ11 Gene of a Neonate with Congenital Hyperinsulinism and Successful Management with Sirolimus. J Clin Res Pediatr Endocrinol 2016;8:478-481. Epub 2016 May 16

151. Méder Ü, Bokodi G, Balogh L, Körner A, Szabó M, Pruhova S, Szabó AJ. Severe Hyperinsulinemic Hypoglycemia in a Neonate: Response to Sirolimus Therapy. Pediatrics 2015;136:e1369-1372.

152. Shah P, Arya VB, Flanagan SE, Morgan K, Ellard S, Senniappan S, Hussain K. Sirolimus therapy in a patient with severe hyperinsulinaemic hypoglycaemia due to a compound heterozygous ABCC8 gene mutation. J Pediatr Endocrinol Metab 2015;28:695-699.

153. Korula S, Chapla A, Priyambada L, Mathai S, Simon A. Sirolimus therapy for congenital hyperinsulinism in an infant with a novel homozygous KCNJ11 mutation. J Pediatr Endocrinol Metab 2017 pii: /j/jpem.aheadof-print/jpem-2017-0238/jpem-2017-0238.xml. doi: 10.1515/jpem-20170238.

154. Al-Balwi R, Al-Atawi M, Al-Otaibi A, Babiker O, Al-Mutair A. Sirolimus in the treatment of three infants with diffuse congenital hyperinsulinism. J Pediatr Endocrinol Metab 2017;30:1013-1017.

155. Sankhala K, Mita A, Kelly K, Mahalingam D, Giles F, Mita M. The emerging safety profile of mTOR inhibitors, a novel class of anticancer agents. Target Oncol 2009;4:135-142. Epub 2009 Apr 21

156. Szymanowski M, Estebanez MS, Padidela R, Han B, Mosinska K, Stevens A, Damaj L, Pihan-Le Bars F, Lascouts E, Reynaud R, Ferreira C, Bansept C, de Lonlay P, Saint-Martin C, Dunne MJ, Banerjee I, Arnoux JB. mTOR Inhibitors for the Treatment of Severe Congenital Hyperinsulinism: Perspectives on Limited Therapeutic Success. J Clin Endocrinol Metab 2016;101:4719-4729. Epub 2016 Oct 3 
157. De León DD, Crutchlow MF, Ham JY, Stoffers DA. Role of glucagon-like peptide- 1 in the pathogenesis and treatment of diabetes mellitus. Int J Biochem Cell Biol 2006;38:845-859. Epub 2005 Sep 15

158. Thorens B. Expression cloning of the pancreatic beta cell receptor for the gluco-incretin hormone glucagon-like peptide 1. Proc Natl Acad Sci U S A 1992;89:8641-8645

159. Gromada J, Holst JJ, Rorsman P. Cellular regulation of islet hormone secretion by the incretin hormone glucagon-like peptide 1. Pflugers Arch 1998;435:583-594.

160. Renström E, Eliasson L, Rorsman P. Protein kinase A-dependent and -independent stimulation of exocytosis by cAMP in mouse pancreatic B-cells. J Physiol 1997;502:105-118

161. Edwards CM, Todd JF, Mahmoudi M, Wang Z, Wang RM, Ghatei MA, Bloom SR. Glucagon-like peptide 1 has a physiological role in the control of postprandial glucose in humans: studies with the antagonist exendin 9-39. Diabetes 1999;48:86-93.

162. Schirra J, Sturm K, Leicht P, Arnold R, Göke B, Katschinski M. Exendin(9-39) amide is an antagonist of glucagon-like peptide-1 (7-36)amide in humans. J Clin Invest 1998;101:1421-1430.

163. De León DD, Li C, Delson MI, Matschinsky FM, Stanley CA, Stoffers DA. Exendin-(9-39) corrects fasting hypoglycemia in SUR-1- mice by lowering CAMP in pancreatic beta-cells and inhibiting insulin secretion. J Biol Chem 2008;283:25786-25793. Epub 2008 Jul 17

164. Calabria AC, Li C, Gallagher PR, Stanley CA, De León DD. GLP-1 receptor antagonist exendin-(9-39) elevates fasting blood glucose levels in congenital hyperinsulinism owing to inactivating mutations in the ATPsensitive K + channel. Diabetes 2012;61:2585-2591. Epub 2012 Aug 1

165. Ng CM, Tang F, Seeholzer SH, Zou Y, De León DD. Population pharmacokinetics of exendin-(9-39) and clinical dose selection in patients with congenital hyperinsulinism. Br J Clin Pharmacol 2017 doi: 10.1111/ bcp.13463.

166. Nehlig A, Pereira de Vasconcelos A. Glucose and ketone body utilization by the brain of neonatal rats. Prog Neurobiol 1993;40:163-221.

167. Owen OE, Morgan AP, Kemp HG, Sullivan JM, Herrera MG, Cahill GF Jr. Brain metabolism during fasting. J Clin Invest 1967;46:1589-1595.

168. Yudkoff M, Daikhin Y, Nissim I, Lazarow A, Nissim I. Ketogenic diet, amino acid metabolism, and seizure control. J Neurosci Res 2001;66:931-940.

169. Yamada KA, Rensing N, Thio LL. Ketogenic diet reduces hypoglycemiainduced neuronal death in young rats. Neurosci Lett 2005;385:210-214.

170. Maiorana A, Manganozzi L, Barbetti F, Bernabei S, Gallo G, Cusmai R, Caviglia S, Dionisi-Vici C. Ketogenic diet in a patient with congenital hyperinsulinism: a novel approach to prevent brain damage. Orphanet J Rare Dis 2015;10:120

171. Sempoux C, Guiot Y, Jaubert F, Rahier J. Focal and diffuse forms of congenital hyperinsulinism: the keys for differential diagnosis. Endocr Pathol 2004;15:241-246.

172. Verkarre V, Fournet JC, de Lonlay P, Gross-Morand MS, Devillers M, Rahier J, Brunelle F, Robert JJ, Nihoul-Fékété C, Saudubray JM, Junien C. Paternal mutation of the sulfonylurea receptor (SUR1) gene and maternal loss of $11 \mathrm{p} 15$ imprinted genes lead to persistent hyperinsulinism in focal adenomatous hyperplasia. J Clin Invest 1998;102:1286-1291.

173. Sempoux C, Capito C, Bellanné-Chantelot C, Verkarre V, de Lonlay P, Aigrain Y, Fekete C, Guiot Y, Rahier J. Morphological mosaicism of the pancreatic islets: a novel anatomopathological form of persistent hyperinsulinemic hypoglycemia of infancy. J Clin Endocrinol Metab 2011;96:3785-3793. Epub 2011 Sep 28

174. Garg PK, Lokitz SJ, Truong L, Putegnat B, Reynolds C, Rodriguez L, Nazih R, Nedrelow J, Guardia M, Uffman JK, Garg S, Thornton PS. Pancreatic uptake and radiation dosimetry of 6-[18F]fluoro-L-DOPA from PET imaging studies in infants with congenital hyperinsulinism. PLoS One 2017;12:e0186340.

175. Hardy OT, Hernandez-Pampaloni M, Saffer JR, Scheuermann JS, Ernst LM, Freifelder R, Zhuang H, MacMullen C, Becker S, Adzick NS, Divgi C, Alavi A, Stanley CA. Accuracy of [18F]fluorodopa positron emission tomography for diagnosing and localizing focal congenital hyperinsulinism. J Clin Endocrinol Metab 2007;92:4706-4711. Epub 2007 Sep 25

176. Christiansen CD, Petersen H, Nielsen AL, Detlefsen S, Brusgaard K, Rasmussen L, Melikyan M, Ekstrom K, Globa E, Rasmussen AH, Hovendal C, Christesen HT. 18F-DOPA PET/CT and 68Ga-DOTANOC PET/CT scans as diagnostic tools in focal congenital hyperinsulinism: a blinded evaluation. Eur J Nucl Med Mol Imaging 2017.

177. Han B, Newbould M, Batra G, Cheesman E, Craigie RJ, Mohamed Z, Rigby L, Padidela R, Skae M, Mironov A, Starborg T, Kadler KE, Cosgrove KE, Banerjee I, Dunne MJ. Enhanced Islet Cell Nucleomegaly Defines Diffuse Congenital Hyperinsulinism in Infancy but Not Other Forms of the Disease. Am J Clin Pathol 2016;145:757-768.

178. Zhang W, Liu L, Wen Z, Cheng J, Li C, Li X, Niu H, Wang F, Sheng H, Liu H. A compound heterozygous mutation of $\mathrm{ABCC} 8$ gene causing a diazoxideunresponsive congenital hyperinsulinism with an atypical form: Not a focal lesion in the pancreas reported by ${ }^{18} \mathrm{~F}$-DOPA-PET/CT scan. Gene 2015;572:222-226. Epub 2015 Jul 8

179. Kühnen P, Matthae R, Arya V, Hauptmann K, Rothe K, Wächter S, Singer M, Mohnike W, Eberhard T, Raile K, Lauffer LM, Iakoubov R, Hussain K, Blankenstein O. Occurrence of giant focal forms of congenital hyperinsulinism with incorrect visualization by (18) F DOPA-PET/CT scanning. Clin Endocrinol (Oxf) 2014;81:847-854. Epub 2014 May 19

180. Capito C, de Lonlay P, Verkarre V, Jaubert F, Rahier J, Nihoul-Fékété C, Aigrain Y. The surgical management of atypical forms of congenital hyperinsulinism. Semin Pediatr Surg 2011;20:54-55.

181. Mohnike K, Blankenstein O, Minn H, Mohnike W, Fuchtner F, Otonkoski T. [18F]-DOPA positron emission tomography for preoperative localization in congenital hyperinsulinism. Horm Res 2008;70:65-72. Epub 2008 Jun 12

182. Otonkoski T, Näntö-Salonen $K$, Seppänen $M$, Veijola $R$, Huopio $H$, Hussain K, Tapanainen P, Eskola O, Parkkola R, Ekström K, Guiot Y, Rahier J, Laakso M, Rintala R, Nuutila P, Minn H. Noninvasive diagnosis of focal hyperinsulinism of infancy with [18F]-DOPA positron emission tomography. Diabetes 2006;55:13-18.

183. Rahier J, Sempoux C, Fournet JC, Poggi F, Brunelle F, Nihoul-Fekete C, Saudubray JM, Jaubert F. Partial or near-total pancreatectomy for persistent neonatal hyperinsulinaemic hypoglycaemia: the pathologist's role. Histopathology 1998;32:15-19.

184. Arya VB, Senniappan S, Demirbilek H, Alam S, Flanagan SE, Ellard S, Hussain K. Pancreatic endocrine and exocrine function in children following near-total pancreatectomy for diffuse congenital hyperinsulinism. PLoS One 2014;9:e98054.

185. Beltrand J, Caquard M, Arnoux JB, Laborde K, Velho G, Verkarre V, Rahier J, Brunelle F, Nihoul-Fékété C, Saudubray JM, Robert JJ, de Lonlay P. Glucose metabolism in 105 children and adolescents after pancreatectomy for congenital hyperinsulinism. Diabetes Care 2012;35:198-203. Epub 2011 Dec 21

186. Ludwig A, Ziegenhorn K, Empting S, Meissner T, Marquard J, Holl R; Diabetes Patienten-Verlaufsdokumentationssystem (DPV) Group, Mohnike K. Glucose metabolism and neurological outcome in congenital hyperinsulinism. Semin Pediatr Surg 2011;20:45-49.

187. Lord K, Radcliffe J, Gallagher PR, Adzick NS, Stanley CA, De León DD. High Risk of Diabetes and Neurobehavioral Deficits in Individuals With Surgically Treated Hyperinsulinism. J Clin Endocrinol Metab 2015;100:4133-4139. Epub 2015 Sep 1

188. Meissner T, Wendel U, Burgard P, Schaetzle S, Mayatepek E. Long-term follow-up of 114 patients with congenital hyperinsulinism. Eur J Endocrinol 2003; 149:43-51

189. Menni F, de Lonlay P, Sevin C, Touati G, Peigné C, Barbier V, NihoulFékété C, Saudubray JM, Robert JJ. Neurologic outcomes of 90 neonates and infants with persistent hyperinsulinemic hypoglycemia. Pediatrics 2001;107:476-479.

190. Ludwig A, Enke S, Heindorf J, Empting S, Meissner T, Mohnike K. Formal Neurocognitive Testing in 60 Patients with Congenital Hyperinsulinism. Horm Res Paediatr 2017. 